This repont was prepared

sponsored by the Urepared 21 an account of work Fened Staten nor the Government. Neither Wewerch and Development Adninist State Energy eubcontmoloyes, nor any of their corn any of

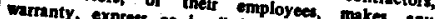
tiability or mpens or implied, or amumes any any os usefulnes of any infor the eccuracy, completerea process dieclosed, or repreaton, apparatus, product of bringe privetely or represents that lis une would not
MITRE Technical Report

MTR-7241

C00/2693-76/2

Distribution Category UC-66

\title{
Methodology for Ranking Geothermal Reservoirs in Non-Electric Industrial Applications
}

\author{
O.G. FARAH \\ F. WILLIAMS
}

THE MITRE CORPORATION WESTGATE RESEARCH PARK

MCLEAN, VIRGINIA 20854

\section{DATE PUBLISHED-MAY 1976}

\author{
PREPARED FOR THE UNITED STATES \\ ENERGY RESEARCH AND DEVELOPMENT \\ ADMINISTRATION \\ DIVISION OF GEOTHERMAL ENERGY \\ UNDER CONTRACT NO: E(11-1)-2693
}

This document was prepared for authorized distribution.

It has not been approved for public release.

PROJECT NO, 3740, DEPT. W-52

DISTRIBUTION OF THIS DOCUMENT IS UNLIMITED 


\section{DISCLAIMER}

This report was prepared as an account of work sponsored by an agency of the United States Government. Neither the United States Government nor any agency Thereof, nor any of their employees, makes any warranty, express or implied, or assumes any legal liability or responsibility for the accuracy, completeness, or usefulness of any information, apparatus, product, or process disclosed, or represents that its use would not infringe privately owned rights. Reference herein to any specific commercial product, process, or service by trade name, trademark, manufacturer, or otherwise does not necessarily constitute or imply its endorsement, recommendation, or favoring by the United States Government or any agency thereof. The views and opinions of authors expressed herein do not necessarily state or reflect those of the United States Government or any agency thereof. 


\section{DISCLAIMER}

Portions of this document may be illegible in electronic image products. Images are produced from the best available original document. 
m.

MITRE Department
and Project Approval: 


\section{ABSTRACT}

It is the goal of ERDA/DGE to st Imulate the development of geothermal energy in the U.S. A large number of geothermal reservoirs exist and to perform a thorough study of each of these reservoirs to determine those most desirable for demonstration projects can be costly and time consuming. A methodology for assigning rankings to these reservoirs, given a limited amount of data, is presented in this paper. The top ranked reservoirs would then be studied more thoroughly. In addition, a methodology for ranking the large number of industries that could possibly utilize geothermal energy in nonelectric applications is given to determine those industries which will have the most impact on national energy demand if converted to geothermal use. 


\section{ACKNOWLEDGEMENT}

The authors wish to thank Mr. Martin M. Scholl whose contribution ultimately gave shape to this report. They are also grateful to the MITRE Geothermal Energy Systems Group for their support and especially to Mr. Ranvir Trehan for his special contribution to Section 2 of this report: 
TABLE OF CONTENTS

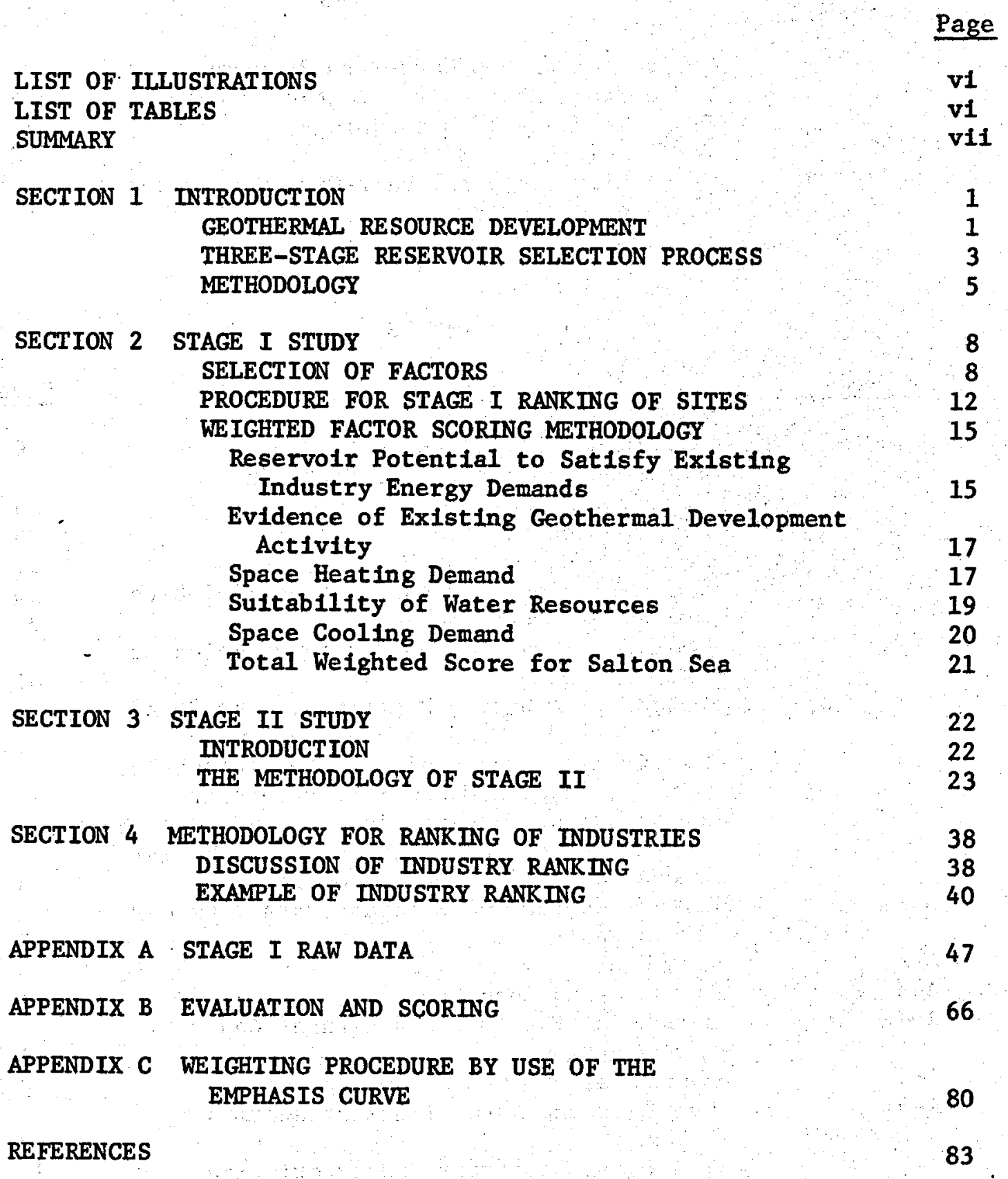


LIST OF ILLUSTRATIONS

Figure Number

Page

1
2
3
$A-1$
$C-1$

Proposed ERDA/DGE Near-Term Program

$x$

Three-Stage Reservoir Selection Process 4

Steps In Stage II Methodology 24

California Study Sites

Triangular Array for Pair-Wise Comparison

of Ten Criteria

\section{LIST OF TABLES}

Table Number

Page

1

2

3

4

5

6

7.

8

9

10

$A-1$

A-2

A-3

A-4

A-5

A-6

A-7

A-8

A-9

A-10

B-1

B-2

Factors Considered and Discarded

Factor Scores for Sample Sites in California

Site Characteristics

Industry Requirements

Explanation of Entries in Stage II Tables 28

Site Transformation

Total U.S. Energy Consumption of Selected Industries

Hydrothermal Energy Distribution by State for $90-150^{\circ} \mathrm{C}$ Temperature Reservolrs

Relative Importance of Selected Industries in States with Geothermal Reservoirs

Comparison of Industry Index with and without Inclusion of the Two Large Hydrothermal Reservoirs in Idaho and Oregon

Factors Chosen and Relevant Data from Raw Data Tables

Land Use

Business and Industry

51

Industrial Fuel 0 il and Natural Gas Consumption

Industrial Production by County

Petroleum and Natural Gas Production by County

Geothermal Reservoir Characteristics

Energy and Utilities

Population and Degree Days

Air and Water Quality

Evaluation Source-Industry Combination

Resource Site/Industry Scores 


\section{SUMPIARY}

One of the objectives of ERDA's geothermal energy RD\&D program is to assist industry in the rapid future exploitation of the more extensive geothermal resources by facilftating near-term Industrial development of identified hydrothermal resources. These Identified resources may in some cases be economically used for electric generation; however, the majority of identified hydrothermal reservoirs are in the moderate temperature range, less than $90^{\circ} \mathrm{C}$, where economic electric applications are not likely in the near future. For these reservoirs, and for higher temperature reservoirs where combined electric and non-electric applications are possible, reservoir development planning based on assessment of specific uses of geothermal fluid at specific sites should be initlated. Such planning is important not only to accelerate the development of specific reservoirs but also to provide the data base for effective evaluation of RD\&D needs at the national level.

The concept of planning based on reservolr-specific prospectuses has been developed and presented in the MITRE Technical Report Geothermal Energy Resource Utilization Program Planning, MTR-7137, March 1976.

In implementing the concept of prospectus-oriented planning it is necessary to establish early a method of selecting reservolrs for prospectus development. A thorough study of the reservolrs to rank order them, although desirable, would be very costly and time-consuming. 
The methodology presented in this paper would help provide the data needed to rank order reservoirs and would provide ERDA with the necessary information to allow informal dectsion making.

The acquisition of planning data has been divided into three stages. In Stage $I$, the set of geothermal reservoirs is examined using readily available data and rough estimating parameters, and the reservoirs are ranked according to their development potential. This Stage I study can be made quickly at the rate of approximately one or two man-days per reservoir. Following this, in Stage II, the reservoirs with the highest Stage I rankings are studied. The Stage II study is more detafled, and the main emphasis is on determining the degree of match between the site/reservoir characteristics and the requirements for both existing and new industry. As a potentially large number of industries need to be examined to determine their energy and siting characteristic requirements, a separate procedure has been developed to establish industry priorities for carring out these analyses. Stage II studies require a good knowledge of the reservoir and its surroundings and therefore should be conducted by a regional agent familiar with the area in question. On the average it is estimated that the data acquisition for a Stage II study will require around one to two man-months per reservoir. The ranking of all the reservoirs selected for studies would take another month or two. Following the Stage II studies is the stage of prospectus development. The reservoirs ranked highest in Stage II 
would be studied further and prospectuses developed for them by reservoir contractors.

The advantage of the methodology presented is that results are continuously available for decision making while the data base for such decision making is being improved. Of course, the more advanced the studies are the better the quality of these decisions. Recommended DGE Strategy

There are certain known reservoirs which, although not ranked against all other reservoirs, have shown potential for and are in various stages of development. Moving ahead with studies and development of these reservolrs, in parallel with the process defined herein, will help accelerate overall development of non-electric applications, and in addition will provide an improved data base for this planning and evaluation procedure.

A rational strategy for DGE should thus consist of simultaneous support of both the ongoing R\&D work and the data acquisition required for establishing reservoir development priorities and selecting new non-electric applications for study and RD\&D. Figure 1 depicts such a strategy. The data acquisition for a Stage I study should take about five months. Following this a Stage I reservoir would be selected for study in Stage II. Work could begin early on the generation of the generic industry requirements. This work would be completed in time for the Stage II studies. 
PROPOSED NEAR TERM GEOTHERMAL PROGAAM

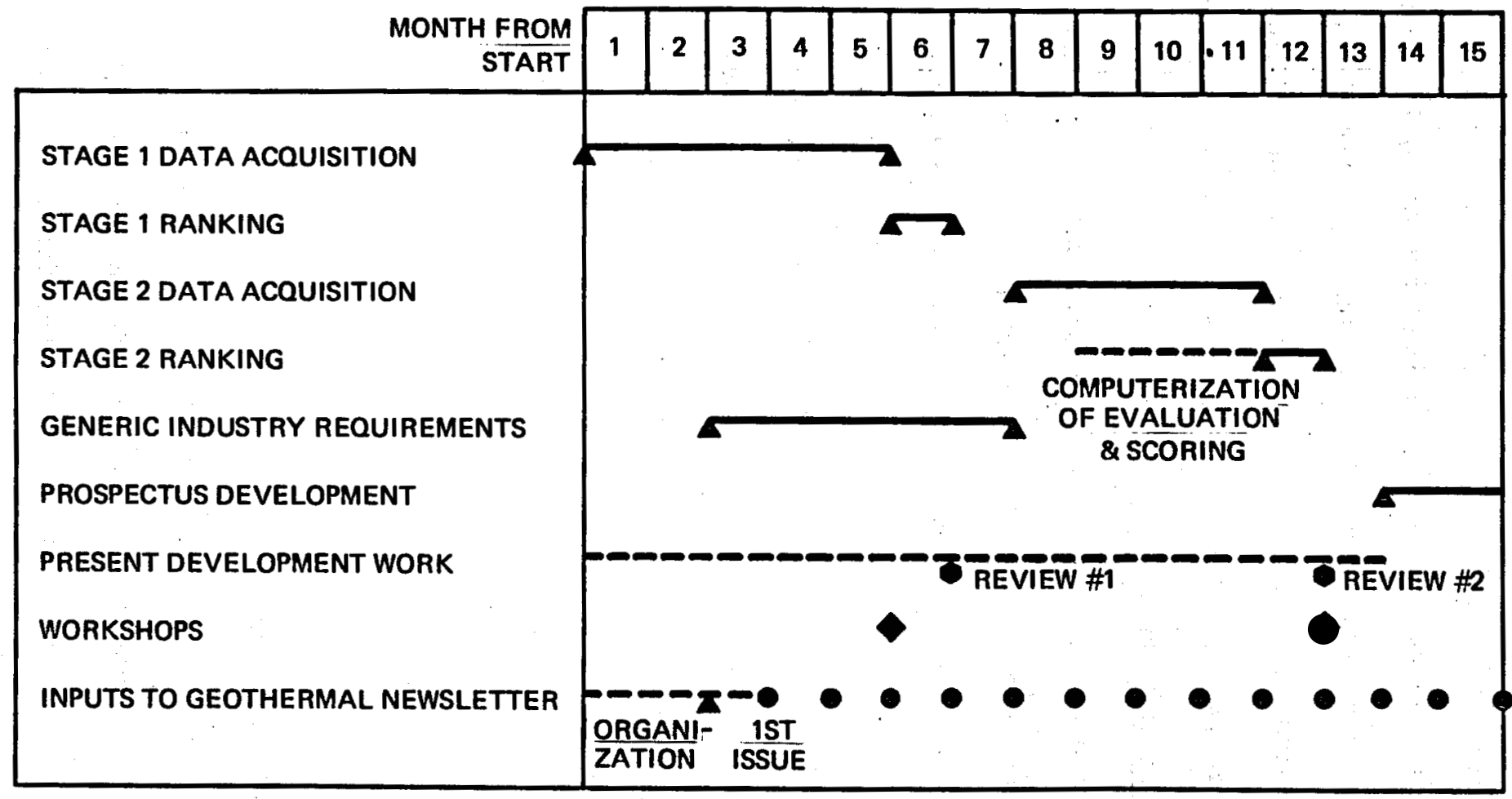

FIGURE:1

PROPOSED ERDA/DGE NEAR-TERM PROGRAM 
The site/reservoir data collection for Stage II studies could begin about seven months after the start of Stage I. Although the data are more complicated they should require less elapsed time to collect than Stage I data since reservoirs may be studied by different agents simultaneously. The data for a Stage II evaluation would become avallable about four months from the beginning of that effort. Stage II ranking could take one to two months including revisions to the ranking methodology. To simplify this procedure, a computer program would be prepared beforehand.

The ongoing RD\&D work would continue, and could be reviewed and revised, if necessary, after each stage. The results of the ongoing work, especially the engineering and economic studies soon to be funded by DGE and the heat exchanger R\&D work presently under way, should have an invaluable effect on the evaluation and scoring in the Stage II studies. A workshop could be held after completion of Stage II and prior to the beginning of prospectus development to allow ERDA/DGE to evaluate the program to date and obtain the opinion of Industry on program composition and training. 
SECTION 1

\section{INTRODUCTION}

GEOTHERMAL RESOURCE DEVELOPMENT

One of the most important objectives of ERDA's Division of Geothermal Energy (DGE) is to stimulate the early development of a geothermal industry in such a way as to enable it to expand, as new technology becomes available, Into utilization of the more expansive and difficult-to-utilize resources. In pursult of this goal the DGE must explore many aspects of hydrothermal and geopressured reservoir development and technology applications, both electric and non-electric. This study considers specifically the non-electric aspects of utilization of the geothermal energy resource.

The mere fact of existence of a geothermal reservolr at some location in the U.S. Is not sufficlent to warrant its development and/or initlation of demonstrations. Many factors affect Its appropriate development, and this study presents a methodology for assessing these factors in terms of the suitability of a given reservoir for development. For example, the following questions must be answered favorably for a particular reservolr to become a candidate for more detalled study:

(1) Is it technologically possible to use the heat from that particular geothermal reservoir as an energy source for a particular energy-consuming process?

(2) Is it economical to use this energy source in that process? And if not, would the use of such energy improve the long-term 
availability and reliability of the energy. supply required for that process?

(3) Will there be institutional or demographic obstacles to the use of the geothermal reservoir?

A great deal of information, time, and effort are required to answer the above questions properly for all hydrothermal and geopressured reservoirs. Unfortunately, some of the needed data may not be easily obtained due to time and cost factors, or because the information is not available (for example, a method has not yet been found to reliably estimate the life of a reservoir). A complete study of a reservoir which could include a plan for reservoir development would result in a prospectus for that reservoir which would be of great value to both industry and the government. (The concept of reservoir development prospectus as a tool to stimulate resource utilization and as a basis for planning the ERDA RD\&D program is discussed in the MITRE Technical Report, MTR-7137. (1), A prospectus study would require approximately one to two man-years to complete. The U.S. Geological Survey in their assessment of U.S. geothermal resources, Circular $726^{(2)}$ lists 66 hydrothermal reservoirs having temperatures over $150^{\circ} \mathrm{C}$ and more than 200 reservoirs with temperatures between $90^{\circ} \mathrm{C}$ and $150^{\circ} \mathrm{C}$. The Circular also identifies 21 geopressured-geothermal subareas. It is true that some of the reservoirs tend to occur in clusters, and hence some of the information needed to assess their development potential may be common to all. Even then, however, the 
cost of developing the required prospectuses may not be justified when one considers that some of those reservolrs are unlikely to be developed in the foreseeable future.

THREE-STAGE RESERVOIR SELECTION PROCESS

In this paper, a three-stage process (shown in Figure 1) is defined. The first two stages select specific reservolrs for prospectus development, with Stage III being the prospectus development itself. In the first two stages the reservoirs and the characteristics of the region surrounding the reservoir are tested against a 1Imited number of selected criteria and rank ordered in terms of desirability for non-electric application development. Each succeeding stage will require more information. To illustrate: Stage I Is designed to allow a quick determination of a number of characteristics of a reservolr and the area surrounding 1t: The information for this stage may be found in the open literature and should take on the average no more than one man-day per reservolr to collect and analyze. Based on these characteristics, a welghted score representing nonelectric development potential may be given to each reservolr. The reservoirs with the highest scores may then be studied more thoroughly In Stage II. In this second stage, Information on the region, demography, and more detailed information on the local industry and raw materlals will be evaluated along with several institutional factors. This information may again be used to determine a Stage II weighted score for each reservoir. Existing local Industry as well 


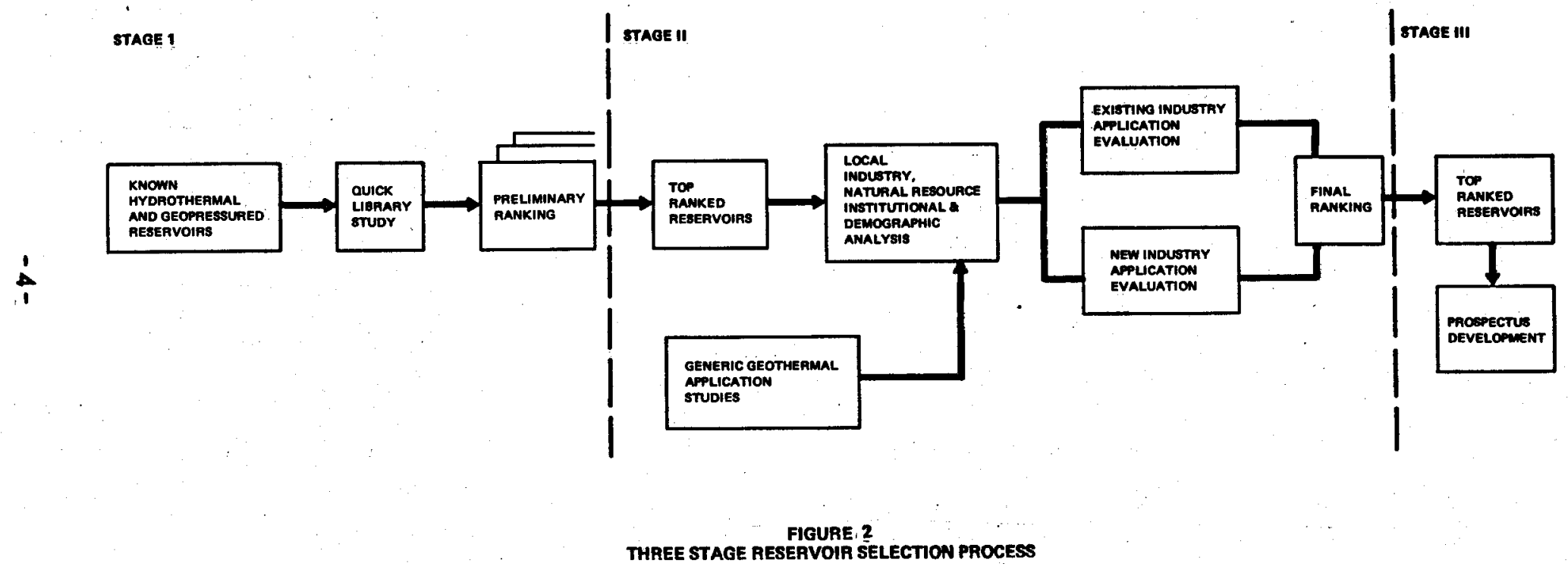

C 
as potential new Industry will be considered. The Industries will be ranked according to their relative Importance from a national standpoint. A preliminary methodology for this Stage II ranking is also defined in this paper. For a Stage II study, it is suggested that a regional contractor familiar with the region under study be selected to obtain the necessary information. It is expected that such a study may require one to three man-months per region to complete. The results of Stage II studies will allow more precise rank ordering of the reservolrs selected In the Stage I study. Prospectuses for the top reservoirs in the Stage II ranking may then be developed. For prospectus development, the use of a contractor familiar with the specific locale surrounding the reservoir is recommended.

\section{METHODOLOGY}

In carrying out this staged approach, it is important not to eliminate reservoirs of high development potential because of inaccuracy or unavallability of data. Thus, the Stage I procedure is designed to lean toward the positive, or higher rankings. The top-ranked reservolr will not necessarily be the best reservoir for development, but it will be one of the most promising. The methodology for ranking the reservolrs in Stages $I$ and II of this study consists of giving a score to a reservoir according to its characterIstics as compared to absolute criteria. Thus, if new information becomes available on a previously unknown reservoir, it will be possible to develop a score for this new reservolr independently of previous evaluations of other reservolrs. 
Another Important aspect of the methodology is that each stage may help to establish the data requirements for the next stage, such that the development of prospectuses can be made highly site-specific and hence more useful to industry and the government.

In general, it is expected that the reservoirs in Stage I will be ranked by a weighted score, which depends on:

(1) The reservoir potential to satisfy existing industry energy demands and the size of reservolr as indication of its potential to attract new industry.

(2) Evidence of existing geothermal development activity.

(3) Space heating and cooling demand.

(4) Suitability of the water resources for industrial and geothermal development.

Stage II consists of a more detalled analysis of the Items above and the following additional criteria:

(5) The feastbility of processing local raw materials using geothermal energy, and hence the potential for industrial development with the geothermal reservoir as the energy source.

(6) The adequacy of the transporation system to support Industrial expansion.

(7) The demographic and institutional characteristics of the region including its population makeup and attitudes, its history, Its infrastructure, and 1 ts rules and regulations as they affect geothermal reservoir development.

(8) The history and attitudes of the financial institutions who may fund development projects at the reservoir.

(9) The environment and climate of the region including the potential for the region to draw people and labor to the area.

(10) The possible restrictions that may result from the present ownership of land. 
The results of the Stage II study may be used to select reservolrs for development of prospectuses. 
SECTION 2

STAGE I STUDY

\section{SELECTION OF FACTORS}

The framework for the Stage I study incorporates the following assumptions and parameters:

(1) Limitation to 30 -mile radius of a given geothermal site*. Because the transmission range of hot brine is Iimited, and because of the probability that the geothermal resource extends beyond the actual drilling hole, site studies are to include all data relevant to a 30-mile radius of the known geothermal reservolr.

(2) Use of only common factors and readily obtainable data. Information for each factor common to all sites is needed to establish a balančed weighting system. The large number of sites and the need for efficient screening makes it necessary that data be quickly and easily obtainable.

(3) Use of only those factors clearly related to geothermal development. Because of the rigidity inherent in a welghting system, only those factors with clearly favorable or unfavorable implications toward geothermal development should be used.

(4) Emphasis on existing Industry. Geothermal applications in existing Industry are emphasized because of the Immediate market potential. Consideration of geothermal applications with respect to

*Unt1l recently, economic transport of geothermal fluid was considered to be limited to about 11 miles of the reservolr. Greater distances are now thought to be practical, and on carrying out Stage I this greater limit may need to be adjusted. This may result in greater effort required to carry out Stage $I$. 
attracting new Industry to the site 1s, to some extent, Indicated by the degree of existing industrialization (industry attracting more industry). However, rigorous analysis of a site's propensity to attract new Industry cannot be done with any validity without the detail inherent in Stage II economic and regional analysis.

To assist in establishing viable factors that could satisfy the above criteria, a preliminary data search was conducted to determine types of readily avallable information. The major references used in the data collection include the U. S. Geological Survey Assessment of Geothermal Resources in the United States - 1975 (C1rcular 726) (2) for reservoir characteristics, as well as U. S. Bureau of the Census statistics, state manufacturers' registers, and water, commercial, and national atlases. Examples of the raw data collected may be found in Appendix Tables A-2 to A-10.

From the data collected in the preliminary search, factors were selected for application to each geothermal site. It became evident that a disparity exists between the information that could be most useful and information that is readily avallable. For instance, although alr quality standards and Information on the salinity of the geothermal resource would have been extremely useful as factors, related data are not available for all of the geothermal sites. Therefore, these factors could not be used as ranking criteria. A list of potentially relevant factors and the rationale for exclusion from this study may be found in Table 1. 
TABLE 1

FACTORS CONSIDERED AND DISCARDED

Pactor Cons1dered

Alr Quality

Industry Temperature Requirements

Salinity of the

Geothermal Resource

$\frac{1}{8}$

Location of Standard

Metropolitan

Stat 18t1cal Areas

Transmission Line and Electric Generation

Plant Location

Transportation

Avallability

\section{Reason for Consideration}

To establish whether future development, including industrial or geothermal, could be banned at a given site due to afr quality and other applicable state regulations.

To determine whether the geothermal resource temperature would be adequate for use in a specific industry.

To determine whether the geothermal resource could be used with a minimum of technological problems relating to salinity (Includes metal corrosion, scale bulldup, etc.)

To be used as an indication of service avallability (schools, hospitals, and transportation, etc.) and the economic character of the region.

As an indication of the feasibility of adding geothermal-electric applications to the region.

As an indication of area potential for supporting new Industry that could be attracted by geothermal use.

\section{Reason for D1scard}

Although the Environmental Protection Agency has required all states to formulate new state air quality standards and implementation plans, many state reports have not yet been completed or approved.

Detalled data on type of process would be required for each industry.

Salinity data are avallable for only a small percentage of geothermal reservolis.

Because of the large area of many SMSAs, and the differential avallability of services, it was determined that SMSA location was of ifinted utility.

Because 1t was decided that the factors in Stage I study should be applicable to all geothermal sites, geothermal-electric considerations are not considered. (Only high-temperature resources over $150^{\circ} \mathrm{C}$, could be used for geothermalover $150^{\circ} \mathrm{C}$, could be used for geothermal-
electric.) It should be noted, however, that the optimal use of higher temperature geothermal reservolrs may be on total energy systems combining electric and non-electric applications.

The existance of a transportation system does not assure room for expansion. Without Stage II information, it is assumed that the transportation system can support existing industry. 
The following are the factors that were selected for the Stage I ranking procedure. The weighting for each factor was established through a pair-wise analysis by MITRE staff working in the geothermal field (see Appendixes $B$ and $C$ for detalls on the factor scoring and weighting). The factors and welghting are as follows:

\section{FACTORS}

WEIGHTING

A. The reservolr potential in satisfying

existing industry energy demands.

B. Evidence of existing geothermal devel-

opment activity.

C. Space heating demand

D. Suitability of water resources.

E. Space cooling demand

The following are some of the assumptions that contributed to the factor weighting decisions:

(1) Industrial energy demands are greater and more easily facilitated by an energy source that is restricted to a given location than are residential energy demands. In addition, the presence of existing industry tends to attract new Industry to a given area, thus increasing the geothermal marketing potential.

(2) Emphasis is given to those sites where an active Interest in geothermal development has already been expressed.

(3) Geothermal space heating applications are given more emphasis than space cooling applications, due to the technological barrlers of space cooling.

(4) The avallability of water is an important consideration in geothermal development. Any new Industrial development would require commensurate water supplles. 
PROCEDURE FOR STAGE I RANKING OF SITES

A three-step procedure has been devised to rank each of the geothermal sites for further study in Stage II. These three steps involve:

(1) Application of all factors to each site to obtain factor scores.

(2) Weighting of each factor score for each site.

(3) Addition of all welghted factor scores for each site, to obtain the "total weighted factor score," which is used in the ranking of sites.

It is important to note that the specificity of this Stage I approach is quite coarse. Perturbations or changes in ranked position of specific reservoirs based on improved data or more detalled evaluation methods are to be expected. The approach is sufficient, however, to identify the candidate 50 to 75 reservolrs for Stage II studies.

In addition to using the factors for site ranking, the approach provides a first-cut indication of the upper bounds for market penetration of geothermal use. This indicator for the upper limit of Industrial-geothermal potential may be obtalned by totaling the energy consumption estimated for each Individual industry. Assuming that the average house size for each site can be determined (a significant element in determining heating and cooling requirements), an indicator for the upper bounds for space heating and cooling. applications can similarly be found. If the total amount of energy used for Industry and space heating and cooling within geothermal 
areas is insignificant, then it may not be useful to further pursue the study of geothermal applications at that site.

Tables A-1 to A-10 in Appendix A include data for arbitrarily chosen high-temperature geothermal reservoirs in California (see Figure A-1 for site locations). The results of Stage I application to each of these reservoirs may be found in Table 2 .

As mentioned previously, the Stage I study is not of sufficient resolution to allow the conclusion that one site whose weighted factor score is slightly larger than another site has a definitely greater potential for non-electric geothermal development. However, using the sample sites in Table 2, it is evident that the Stage I methodology makes it possible to conclude that certain groups of reservoirs have more potential for geothermal development than do other groups. For Instance, one may definitely conclude that Long Valley, Brawley, Heber, and East Mesa (each of which has a weighted factor score of 72 and above) have more non-electric geothermal development potential than do Border, Sespe, and Coso (which scored 28 or below). The type of geothermal development potential of each reservoir may also be construed from Table 2. For instance, factor scores Indicate that Salton Sea, Brawley, Heber, and Long Valley are potential candidates for industrial geothermal use, whereas factor scores for Sespe, Long Valley, and $\operatorname{Red}^{\prime} s$ Meadow Indicate potential for geothermal space heating applications.

The remainder of this section describes, In detail, the steps necessary for performing the actual ranking procedure. Included are 
TABLE 2

FACTOR SCORES FOR SAMPLE SITES IN CALIFORNIA

\begin{tabular}{|c|c|c|c|c|c|c|}
\hline SITE & $\begin{array}{l}\text { RESERVOIR POTENTIAL } \\
\text { IN SATISFYING EXISTING } \\
\text { INDUSTRY ENERGY DEMAND }\end{array}$ & $\begin{array}{c}\text { EVIDENCE OF } \\
\text { EXISTING GEOTHERMAL } \\
\text { DEVELOPMENT ACTIVITY }\end{array}$ & $\begin{array}{l}\text { SPACE HEATING } \\
\text { DEMAND }\end{array}$ & $\begin{array}{l}\text { SUITABILITY OF } \\
\text { WATER RESOURCES }\end{array}$ & $\begin{array}{l}\text { SPACE COOLING } \\
\text { DEMAND }\end{array}$ & $\begin{array}{l}\text { TOTAL } \\
\text { WEIGRTED } \\
\text { SCORE }\end{array}$ \\
\hline & WEIGHT $=33 \%$ & WEIGHT $=28 \%$ & WEIGHT $=20 \%$ & WEIGHT $=15 \%$ & WEIGHT $=3 \%$ & \\
\hline Salton Sea & $(1)^{\star} \quad 33^{\star \star}$ & (1) & $(.2)$ & (0) & $(.8)$ & 67.4 \\
\hline Brawley & (1) 33 & (1) & $(.4)$ & (0) & (1) & 72.0 \\
\hline Heber & (1) & (1) & $(.4)$ & (0) & (1) & 72.0 \\
\hline East Mesa & (1) & (1) & $(.4)$ & (0) & (1) & 72.0 \\
\hline Border & (0) & (0) & (0) & (0) & (0) & 0 \\
\hline Sespe & $(.08)$ & (0) & (1) & (0) & $(.4)$ & 23.8 \\
\hline Coso & (0) & (1) & (0) & (0) & $(0)$ & 28.0 \\
\hline Long Valley & (1) & (1) & (1) & (1) & $(0)$ & 96.0 \\
\hline Red's Meadow & $(.08)$ & (1) & (1) & (1) & (0) & 65.6 \\
\hline
\end{tabular}

* Factor score

** Weighted factor score 
the rationale for using each factor, and the method for obtaining and weighting the factor scores. The Salton Sea, a high-temperature (over $150^{\circ} \mathrm{C}$ ) geothermal site In California, is used to demonstrate the welghted factor scoring methodology.

WEIGHTED FACTOR SCORING METHODOLOGY

Reservoir Potential to Satisfy Existing Industry Energy Demands

Th1s procedure indicates the potential maximum geothermal energy use for replacing existing energy sources (upper bounds based on estimate of present energy use).

Factor Scoring Procedure

Let $A=$ an estimate of the sum of energy requirements for all industries within 30 miles of the geothermal reservolr

$B=$ heat content of the reservoir

$C=$ the heat content of the average hydrothermal reservoir

$=2.56 \times 10^{18} \mathrm{cal}$ (calculated from data In USGS Circular $726^{(2)}$

Assuming a potential for using one-fourth of the total reservoir heat content (including heat recovery and non-electric system efficlency factors) and that the reservolr w11l be used for a period of at least 25 years, then:
if $B>C$
$x=1$
B $<$ C
$\mathbf{x}=\frac{\mathrm{B}}{\mathrm{C}}$
if $A=0$
$y=0$
$A \neq 0$
$y=1$ 


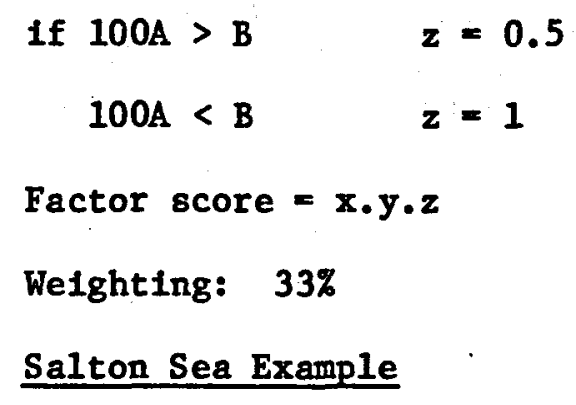

\section{Salton Sea Example}

$A=$ total estimated annual fuel oil and natural gas consumption of industries in:

Ind10

Coachella

Thermal

Calipatria

Brawley

Imperial

$-\mathbf{A}=$

$$
716.59 \times 10^{11}
$$

$$
52.15 \times 10^{11}
$$$$
231.99 \times 10^{11}
$$$$
172.11 \times 10^{11}
$$$$
3559.02 \times 10^{11}
$$

$88.17 \times 10^{11}$

$4820.03 \times 10^{11}$

(consumption data found in Table A-4)

$B=21 \times 10^{18} \mathrm{cal}$.

(reservolr data found in Table A-7)

$C=2.56 \times 10^{18} \mathrm{cal}$.

since $B>C . \quad x=1$

$A \neq 0 \quad y=1$

$100 A<B \quad z=1$

Factor score $=x \cdot y \cdot z=1 \times 1 \times 1=1$

Weighted factor score $=33 \times 1=33$ 
Evidence of Existing Geothermal Development Activity

This procedure is used to Indicate present industrial interest in the geothermal site.

\section{Factor Scoring Procedure}

The factor score $=1$ if either:

(a) Geothermal utilization activities are currently taking place, or

(b) If geothermal leases have been applied for.

The factor score $=0$ if neither (a) nor (b) is applicable.

Weighting: $28 \%$

Salton Sea Example

Geothermal development activity is taking place, factor score $=1$

(use data found in Table A-8)

Weighted factor score $=1 \times 28=28$

Space Heating Demand

The amount of space heating demand is found by the following procedure:

\section{Factor Scoring Procedure}

Let $A=$ the sum of all homes within 30 miles of the geothermal site (assuming four persons per home)

$B=$ an indication of heating load based on degree days, whereby each range of degree days is given the following value: 


\begin{tabular}{|c|c|}
\hline Heating Degree Days & Value of $B$ \\
\hline $0-500$ & 0 \\
\hline $500-1000$ & 1 \\
\hline $1000-2000$ & 2 \\
\hline $2000-3000$ & 4 \\
\hline $3000-4000$ & 8 \\
\hline $4000-5000$ & 16 \\
\hline $5000-6000$ & 32 \\
\hline $6000-7000$ & 64 \\
\hline $7000-8000$ & 128 \\
\hline $8000-9000$ & 256 \\
\hline $9000-10000$ & 512 \\
\hline 10000-above & 1024 \\
\hline
\end{tabular}

Then A $x$ B represents space heating requirements, with higher results indicating a greater possibility for resource utilization. Conversion of A $\times$ B to factor scores is shown as follows:

\begin{tabular}{cc}
\hline A $\times$ B range & Factor score \\
$0-9,999$ & 0 \\
$10,000-19,999$ & 0.2 \\
$20,000-29,999$ & 0.4 \\
$30,000-39,999$ & 0.6 \\
$40,000-49,999$ & 0.8 \\
50,000 and above & 1.0 \\
\hline
\end{tabular}

Weighting: $20 \%$ 
Salton Sea Example

Total population $=23,593$ (use data found in Table A-9)

$A=$ Total number of homes or $\frac{23,593}{4}=5898$ homes

Heating degree days $=1000-2000$ (use data found in Table A-9), $B=2$

$$
A \cdot B=11796.5
$$

Factor score $=0.2$

WeIghted factor score $=0.2 \times 20=4$

Suitability of Water Resources

This procedure provides an indication of whether the water resources in the vicinity of the geothermal resource could support additional industrial or geothermal development.

\section{Factor Scoring Procedure}

The geothermal sites that are in areas without indicated hydrological problems have a factor score $=1$. If problems are indicated, the site score $=0$.

"Problems" are defined as hydrological situations that could limit the development of new industry (such as water shortages, high salinity, or high pollution in existing water supply). . It is assumed that Industrial development will depend, in part, upon water avallability whether or not geothermal use is to occur.

Weighting: $15 \%$

Salton Sea Example

Because water resources in the area are high in salinity, short in supply, and with management difficulty (see Table A-10), 
Factor score $=0$

Weighted factor score $=1.15=0$

\section{Space Cooling Demand}

This factor provides an indication of the amount of space cooling demand in the vicinity of the reservoir.

\section{Factor Scoring Procedure}

Assuming that a minimum geothermal reservoir temperature of $90^{\circ} \mathrm{C}$ is necessary to establish the technical feasibility of absorption cooling, the following should be applied to only those reservoirs whose temperatures exceed $90^{\circ} \mathrm{C}$,*

Let $A=$ the sum of all homes within 30 miles of the geothermal site (assuming four persons per home)

$B=$ the number of cooling degree days such that each range of degrees is given the following value:

\begin{tabular}{lr} 
Cooling Degree Days & Value \\
\cline { 2 - 2 } $0-500$ & \\
$500-1000$ & 1 \\
$1000-2000$ & 2 \\
$2000-3000$ & 4 \\
$3000-4000$ & 8 \\
$4000-$ above & 16
\end{tabular}

Then A x B represents space cooling requirements, with higher results indicating a greater possiblity for resource utilization.

The conversion of A $\times$ B to factor scores shall be as follows:

* At $90^{\circ} \mathrm{C}$, absorption cooling becomes technically feasible; efficlency improves with available temperatures. Using $90^{\circ} \mathrm{C}$ will, as with other criterla, err toward higher scores and greater likelihood of meeting the Stage II evaluation cutoff. 


\begin{tabular}{ll}
\hline Value of A X B & Factor Score \\
\hline below 10,000 & 0 \\
$10,000-20,000$ & 0.2 \\
$20,000-30,000$ & 0.4 \\
$30,000-40,000$ & 0.6 \\
$40,000-50,000$ & 0.8 \\
50,000 and above & 1 \\
\hline
\end{tabular}

If the temperature of the geothermal reservoir $<90^{\circ} \mathrm{C}$, then the factor score is 0 .

Weighting: $3 \%$

\section{Salton Sea Example}

Total population $=23,593$ (use data found in Table A-9)

$A=$ total number of homes of $\frac{23,593}{4}=5898$

cooling degree days $=3000-4000$ (use data found In Table $1-9$ ) so:

$B=8$

$$
\text { A.B }=47,184
$$

Factor score $=0.8$

Welghted factor score $=0.8 \times 3=2.4$

Total Welghted Score for Salton Sea

Sum of all welghted factor scores or:

$$
\begin{gathered}
33.0 \\
28.0 \\
4.0 \\
0 \\
2.4 \\
\hline 67.4
\end{gathered}
$$


SECTION 3

STAGE II STUDY

\section{INTRODUCTION}

Once the Stage I study is completed and the reservoirs are roughly ranked, the top-ranked reservoirs may be studied in more detail in Stage II. Additional information is acquired on the reservoir and its surroundings to permit a more accurate ranking of those reservoirs and selection of those most eligible for prospectus studies.

Whereas in the Stage I analysis the ranking is a reasonable indication of the desirability of developing a reservoir, in the Stage II study the marriage of a reservoir with particular industries is the focus. Reservoir characteristics and industry requirements are analyzed and, with these relationships established, an analytical procedure is used to assess the desirability of developing specific industry/reservoir matches. The analytical procedure developed for this purpose addresses most of the decision-making criteria likely to be used by industry; however, an additional thorough cost/benefit analysis for a specific plant would be required before an industry decides to convert to the use of geothermal energy.

The assignment of a numerical score for each criterion described in this section is a preliminary procedure which has not as yet been tested through its application to specific reservoirs. This preliminary procedure should be refined with more experience in its application. 
The data have been organized in such a way as to allow easy computer1zation at a later time. Thus, when the procedure is refined, recomputing the scores and ranking the sites will be a simple task. It may be advisable to conduct delphis and/or workshops at this early stage to solicit the opinions of potential users of geothermal energy as to the relative importance of the criteria included in Stage II studies.

The Stage II study w11l require both gener1c knowledge of requirements of specific industries (e.g., energy needs, temperature ranges, raw materials and feedstocks, labor, land, product markets, etc.) and extensive knowledge of the region surrounding the reservoirs under consideration. The former may be supplied by the presently conceived Englneering and Economic Studies soon to be funded by DGE. The latter may best be supplied by reglonal agents or reglonal contractors operating in and familiar with the characteristics of the geothermal reservolr areas, and with present industry in their regions, as well as with demography, natural resources, present energy supply, land use, local regulations, institutional constraints, and similar factors.

THE METHODOLOGY OF STAGE II

The methodology for Stage II is depicted in Figure 2. Th1s methodology requires collection of extensive data regarding the region surrounding a given reservolr as well as data on existing Industry in the region and industry not presently in the region but 
GENERIC INDUSTRIAL REQUIREMENTS (TYPICAL PLANTS)

- ENERGY REQUIREMENTS

- RELATEd INDUSTRIES

- Required raw materials

- REQUIRED MANPOWER

- MARKETS FOR PRODUCTS

SITE CHARACTERISTICS

- RESERVOIR CHARACTERISTICS

- REgIONAL INDUSTRIAL PROFILE

- aVAILABLE NATURAL Resources

- LABOR FORCE

- TRANSPORTATION AVAILABLE

- LOCAL MARKET

EXISTING INDUSTRIAL REQUIREMENTS (SPECIFIC COMPANIES)

- ENERGY REQUIREMENTS

- RELATED INDUSTRIES

- REQUiREd RAW MATERIALS

- NEEDED LABOR \& PROFESSIONAL MANPOWER

- MARKETS FOR PRODUCTS

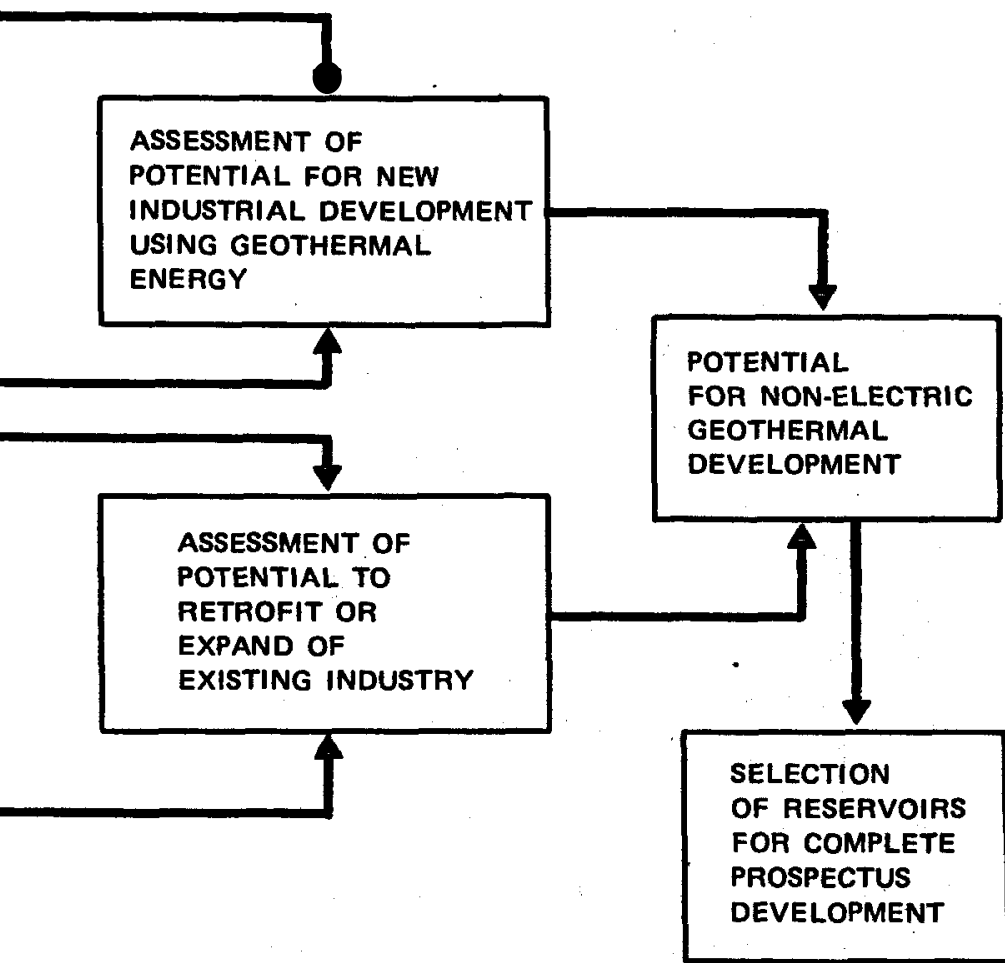

FIGURE 3

STEPS IN STAGE II METHODOLOGY 
with needs which could be satisfled in the region and which could be serviced by geothermal energy. Specific data requirements are shown in Tables 3 and 4, Table 4 applying to both existing and generic Industrial descriptions. These tables are arranged in such a way as to allow anticipated future computerization and to facilitate mapping of characteristics and industrial requirements. In this tabular arrangement a given line (or row) in each table represents the similar criterion.(1.e., the first row describes the geothermal resource characteristics, the second row covers the energy requirements of the applications surrounding the site). Each entry in the tables covers a unique characteristic (e.g., temperature, transportation,...). To simplify location of the characteristics in the tables, the familiar two-dimensional subscript notation has been used (e.g., the subscripts 1,2 refer to row 1 and column 2).

Table 5 explains more fully the entries to be made in Tables 3 and 4 .

The site characteristics table (Table 4) is straightforward and may be assembled without any specific knowledge of geothermal applications at this reservoir.

When site-specific industry tables represent relatively new plants they should, in general, resemble the generic industry tabulations that will characterize state-of-the-art industrial practice. Differences from the generic Industry are 11kely when existing plants are older and/or in poor repa1r. It may be expected, however, that 
TABLE 3
ARACTERISTICS

RESERVOIR:

\begin{tabular}{|c|c|c|c|c|c|c|}
\hline $\begin{array}{l}\text { 'SOURCE } \\
\text { CHARACTERISTICS }\end{array}$ & TEMPERATURE & FLOW RATE & SALINITY & PRESSURE & WELL DEPTH & EXTENT \\
\hline $\begin{array}{l}\text { ENERGY } \\
\text { SUPPLY }\end{array}$ & GAS AND OIL & OTHER FUELS & $\begin{array}{l}\text { POWER GENERATION } \\
\text { AND TRANSMISSION }\end{array}$ & SUPPLY RELIABILITY & EXPANSION RATE & LOCATION \\
\hline EXIST:NG INDUSTRY & $\begin{array}{l}\text { INTERDEPENDENT } \\
\text { INDUSTRIES }\end{array}$ & $\begin{array}{l}\text { INDEPENDENT } \\
\text { INDUSTRIES }\end{array}$ & - & - & - & - \\
\hline $\begin{array}{l}\text { LOCAL AAW } \\
\text { MATERIALS }\end{array}$ & $\begin{array}{l}\text { RAW MATERIAL } \\
\text { REQUIRED FOR ABOVE }\end{array}$ & $\begin{array}{l}\text { RAW MATERIALS } \\
\text { REQUIRED FOR ABOVE }\end{array}$ & $\begin{array}{l}\text { REMAINING RAW MATERIALS } \\
\text { THAT CAN BE PROCESSED } \\
\text { LOCALLY }\end{array}$ & - & - & -- \\
\hline LAND USE & LAND DISTRIBUTION & LAND USE & $\begin{array}{l}\text { MINERALL EXPLOAATION } \\
\text { LEASES }\end{array}$ & - & - & - \\
\hline CLIMATE & $\begin{array}{l}\text { DEGREE-DAYS HEATING } \\
\text { Q COOLING }\end{array}$ & AVERAGE WINO DATA & AVERAGE RAIN DATA & - & $\longrightarrow$ & - \\
\hline $\begin{array}{l}\text { ENVIRONMENTAL STATUS } \\
\text { REGULATIONS }\end{array}$ & $\begin{array}{l}\text { HYDROLOGIC PAOFILE } \\
\text { AND EFFLUENT } \\
\text { RESTRICTION }\end{array}$ & $\begin{array}{l}\text { AIR QUALITY PROFILE } \\
\text { AND EMISSION } \\
\text { RESTRICTION }\end{array}$ & SOLIO WASTE DISPOSAL SITES & SEISMIC ACTIVITY & -- & $-\ldots$ \\
\hline $\begin{array}{l}\text { TRANSPORTATION } \\
\text { SEAVICES \& CENTERS }\end{array}$ & $\begin{array}{l}\text { TRANSPORTATION SYSTEM } \\
\text { (ALL MODES) }\end{array}$ & $\begin{array}{l}\text { INDUSTRIIAL PRODUCTS } \\
\text { CENTERS }\end{array}$ & $\begin{array}{l}\text { COMMERCIAL PRODUCTS } \\
\text { CENTERS }\end{array}$ & $\ldots$ & - & - \\
\hline $\begin{array}{l}\text { DEMOGRAPHIC } \\
\text { CHARAGTERISTICS }\end{array}$ & $\begin{array}{l}\text { NEARS POPULATION } \\
\text { CENTER }\end{array}$ & LOCAL LABOR & LOCAL GROUPS/AGENCIES & COMMUNITY SEAVICES & ATTITUDES & - \\
\hline $\begin{array}{l}\text { INSTITUTIONAL } \\
\text { CHAPACTERISTICS }\end{array}$ & $\begin{array}{l}\text { REGULATIONS, LAWS. } \\
\text { STATUTES }\end{array}$ & - & $\therefore$ & $\ldots$ & - & $\ldots$ \\
\hline $\begin{array}{l}\text { ECONOMIC } \\
\text { CHARACTERISTICS }\end{array}$ & FINANGIAL INST. & - & $\ldots$ & - & $\cdots$ & - \\
\hline
\end{tabular}




\begin{tabular}{|c|c|c|c|c|c|c|}
\hline \multirow{2}{*}{$\begin{array}{l}\text { REQUARED GEOTHERMAL } \\
\text { RESERVOIF } \\
\text { CHARACTERISTICS } \\
\text { ENEROY REOUIREMENTS }\end{array}$} & $\begin{array}{l}\text { TEMPERATURE } \\
\text { LMITS }\end{array}$ & $\begin{array}{l}\text { MEAThAATE } \\
\text { REQuirRED }\end{array}$ & SALIMITY LIMITS & PRESSLPAE LIMTIS & - & $\begin{array}{l}\text { YEARLY ENEROY } \\
\text { CONSSUMTTOON }\end{array}$ \\
\hline & $\begin{array}{l}\text { OOLL GAS } \\
\text { suEsTTUTTED }\end{array}$ & $\begin{array}{l}\text { OTHER FUELS } \\
\text { suESTIVUTEO }\end{array}$ & $\begin{array}{l}\text { ELECTRIC POWER } \\
\text { REQURRE, ASVED, } \\
\text { OR GENERATED }\end{array}$ & $\begin{array}{l}\text { SUPPLY YELLABLLITY } \\
\text { REOURRED }\end{array}$ & $\begin{array}{l}\text { YEARRYY EXPANSION } \\
\text { RATE OF ENERGY } \\
\text { DEMANO }\end{array}$ & $\begin{array}{l}\text { LoCATION OF } \\
\text { INOUSTAY } \\
\end{array}$ \\
\hline \multirow[t]{2}{*}{ RELATED INDUSTRIES } & $\begin{array}{l}\text { RELATED } \\
\text { INOUSTRIES }\end{array}$ & - & - & - & - & - \\
\hline & REOUIREMENTS & - & REQUIREMENTS & - & - & - \\
\hline LANO REOUHREMENTS & $\begin{array}{l}\text { LAND AGGREGATION } \\
\text { REOUREMENTS }\end{array}$ & $\begin{array}{l}\text { LAND CLASSIFICATIONS } \\
\text { REOUIREMENTS }\end{array}$ & $\begin{array}{l}\text { MINERAL EXPLORATION } \\
\text { LEASES REOUIRED }\end{array}$ & - & - & - \\
\hline \multirow[b]{2}{*}{$\begin{array}{l}\text { POOENTIAL ENVIRONMENTAL } \\
\text { LIMTSS }\end{array}$} & $\begin{array}{l}\text { CLIMATE CONTROL } \\
\text { REQUIRED }\end{array}$ & WMND LIMITS & RAN FEQUUREMENTS & $\longrightarrow$ & - & - \\
\hline & WATER POLLUTANTS & AIR POLLUTANTS & SOLIO POLLUTANTS & $\begin{array}{l}\text { EFFECT OF } \\
\text { REINACETON }\end{array}$ & - & - \\
\hline TRANSPORTATION NEEDS & $\begin{array}{l}\text { TRANSPORTATION } \\
\text { REOU!RED }\end{array}$ & 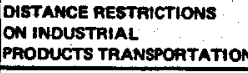 & 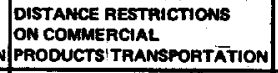 & TONMAGE & $\begin{array}{l}\text { INDUSTRIAL PRODUCT } \\
\text { MARKETS }\end{array}$ & $\begin{array}{l}\text { COMMERCINLL } \\
\text { PrRDOUCT } \\
\text { MARKETS }\end{array}$ \\
\hline DEMOGRAPHIC MEEDS & $\begin{array}{l}\text { REQUiRED CONSUMER } \\
\text { MARKETS }\end{array}$ & LABOR REOUIREMENTS & $\begin{array}{l}\text { OBJECTONALE } \\
\text { CHARACERSTIS } \\
\text { INAREST GROOUPS } \\
\end{array}$ & $\begin{array}{l}\text { REQUARED } \\
\text { comm, SEAV. }\end{array}$ & $\begin{array}{l}\text { OOAECTIONALE } \\
\text { CHARACTERISTICS } \\
\text { COMMUNITY }\end{array}$ & - \\
\hline INSTITUTIONAL FACTORS & $\begin{array}{l}\text { CHARACTERISTTCS HHAT } \\
\text { MAY CONFLCT WTH } \\
\text { AEGULATIONS }\end{array}$ & - & - & $\longrightarrow$ & $\longrightarrow$ & - \\
\hline ECONOMIC MEEDS & 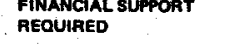 & - & - & $\ldots$ & $\ldots$ & - \\
\hline
\end{tabular}

- FOR ABOVE INDUSTRIES. 
TABLE 5

EXPLANATION OF ENTRIES IN STAGE II TABLES

\begin{tabular}{|c|c|c|c|c|}
\hline & & & LANATION OF ENTRY IN: & \\
\hline ENTRY & CHARACTERISTIC & TABLE 3 & TABLE 4 & TABLE 6 \\
\hline 1,1 & Temperature & $\begin{array}{l}\text { Surface temperature of } \\
\text { geothermal brine }\end{array}$ & $\begin{array}{l}\text { Temperature required by } \\
\text { process }\end{array}$ & $\begin{array}{l}\text { Modifications required } \\
\text { to temperature }(\mathrm{e} \cdot \mathrm{g} \cdot \text {, } \\
\text { heat or cool) }\end{array}$ \\
\hline 1,2 & Flow Rate & $\begin{array}{l}\text { High rated flow rate } \\
\text { for resource }\end{array}$ & $\begin{array}{l}\text { Required Heat Rate } \\
\text { of process }\end{array}$ & $\begin{array}{l}\text { Modifications required } \\
\text { (e.g., by drilling } \\
\text { additional wells). }\end{array}$ \\
\hline 1,3 & Salinity & $\begin{array}{l}\text { Salinity of Geothermal } \\
\text { brine including compo- } \\
\text { sition of salts }\end{array}$ & $\begin{array}{l}\text { Salts not acceptable } \\
\text { by process and } \\
\text { salinity limits }\end{array}$ & $\begin{array}{l}\text { Determine whether de- } \\
\text { salinization required } \\
\text { or secondary working } \\
\text { fluid w/heat exchanger } \\
\text { required }\end{array}$ \\
\hline 1,4 & Pressure & $\begin{array}{l}\text { Well pressure at } \\
\text { surface }\end{array}$ & $\begin{array}{l}\text { Pressure limits of } \\
\text { process }\end{array}$ & Required modifications \\
\hline 1,5 & We11 Depth & We11 depth & No entry & No entry \\
\hline 1,6 & Extent & $\begin{array}{l}\text { Estimated heat } \\
\text { capacity of reservoir }\end{array}$ & $\begin{array}{l}\text { Yearly energy require- } \\
\text { ments of industry }\end{array}$ & $\begin{array}{l}\text { Need for augmenting } \\
\text { non-geothermal energy }\end{array}$ \\
\hline
\end{tabular}


TABLE 5 (Cont ${ }^{\prime} d$ )

\begin{tabular}{|c|c|c|c|c|}
\hline & & & ANATION OF ENTRY IN: & \\
\hline ENTRY & CHARACTERISTIC & TABLE 3 & TABLE 4 & TABLE 6 \\
\hline 2,1 & $011 \&$ Gas & $\begin{array}{l}\text { 011 \& gas consumed } \\
\text { in region }\end{array}$ & $\begin{array}{l}011 \text { \& gas which may be } \\
\text { substituted with } \\
\text { geothermal energy }\end{array}$ & $\begin{array}{l}\text { Net decrease/increase } \\
\text { in ofl \& gas consump- } \\
\text { tion }\end{array}$ \\
\hline 2,2 & Other Fuels & $\begin{array}{l}\text { Other Fuels consumed } \\
\text { in region }\end{array}$ & $\begin{array}{l}\text { Other fuels which may } \\
\text { substituted with } \\
\text { geothermal energy }\end{array}$ & $\begin{array}{l}\text { Net decrease/ increase } \\
\text { in other fuels con- } \\
\text { sumption }\end{array}$ \\
\hline 2,3 & $\begin{array}{l}\text { Power Trans- } \\
\text { mission System }\end{array}$ & $\begin{array}{l}\text { Capacity of present } \\
\text { power transmission/ } \\
\text { distribution system }\end{array}$ & $\begin{array}{l}\text { Electric requirements } \\
\text { of industry and possible } \\
\text { savings due to use of } \\
\text { geothermal energy }\end{array}$ & $\begin{array}{l}\text { Net decrease/increase } \\
\text { in electricity con- } \\
\text { sumption and its } \\
\text { effect on the system } \\
\text { distribution }\end{array}$ \\
\hline 2,4 & $\begin{array}{l}\text { Enorgy Supply } \\
\text { Relfability }\end{array}$ & $\begin{array}{l}\text { Present \& projected } \\
\text { status of supply }\end{array}$ & $\begin{array}{l}\text { Rellability required } \\
\text { by process--years of } \\
\text { reliable supply needed } \\
\text { to commit to establish } \\
\text { or retrofit a plant }\end{array}$ & $\begin{array}{l}\text { Net effect of the use } \\
\text { of geothermal energy } \\
\text { in the process }\end{array}$ \\
\hline 2,5 & Expansion Rate & $\begin{array}{l}\text { Estimated energy de- } \\
\text { mand annual expansion } \\
\text { rate for the region }\end{array}$ & $\begin{array}{l}\text { Estimated energy de- } \\
\text { mand annual expansion } \\
\text { rate for process }\end{array}$ & No entry \\
\hline 2,6 & Location & $\begin{array}{l}\text { Location of geother- } \\
\text { mal resource }\end{array}$ & $\begin{array}{l}\text { Present location of } \\
\text { Industry }\end{array}$ & $\begin{array}{l}\text { Geothermal Fluid } \\
\text { transmission problems } \\
\text { expected, heat losses }\end{array}$ \\
\hline
\end{tabular}


TABLE 5 (Cont'd)

EXPLANATION OF ENTRY IN:

\begin{tabular}{lllll}
\hline ENTRY & CHARACTERISTIC & \multicolumn{1}{c}{ TABLE 3 } & TABLE 4 & TABL \\
3,1 & $\begin{array}{l}\text { Related } \\
\text { Industry }\end{array}$ & $\begin{array}{l}\text { Industries related to } \\
\text { each other displayed } \\
\text { in groups }\end{array}$ & $\begin{array}{l}\text { Types of industry } \\
\text { that would be related } \\
\text { to the industry in } \\
\text { question (competitive } \\
\text { as well as complementary) }\end{array}$ & $\begin{array}{l}\text { Actual ind } \\
\text { region re } \\
\text { industry }\end{array}$ \\
3,2 & $\begin{array}{l}\text { Independent } \\
\text { Industries }\end{array}$ & $\begin{array}{l}\text { Industries which do } \\
\text { not presently relate } \\
\text { to others in the } \\
\text { region }\end{array}$ & No entry & No entry \\
& & &
\end{tabular}

\begin{tabular}{ll}
\hline $4,1 \quad \begin{array}{l}\text { Raw Materials } \\
\text { required for } \\
\text { Related Indus- } \\
\text { tries }\end{array}$ \\
$4,2 \quad \begin{array}{l}\text { Raw Materials } \\
\text { Required for } \\
\text { Independent } \\
\text { Industries }\end{array}$
\end{tabular}

Major raw materials and Major new materials and feedstocks locally grown feedstocks required by manufactured to support the industry being the related industry studied groups and the annual production of those materials

All raw materials and feedstocks locally produced to support the independent industries and the annual production of those materials

All raw materials and feedstocks required by industry if it does not belong to groups above

All raw materials and feedstocks produced locally that have potential for local processing by using geothermal energy

No entry
Those materials which may be used by the industry and the required modifications of local raw materials production to assure success of Industry being studied

Same as above if Industry studied is independent

Same as above if industry studied will utilize those raw materials 
TABLE 5 (Cont $\left.t^{\prime} d\right)$

\begin{tabular}{|c|c|c|c|c|}
\hline \multirow[b]{2}{*}{ ENTRY } & \multirow[b]{2}{*}{ CHARACTERISTIC } & \multicolumn{2}{|c|}{ EXPLANATION OF ENTRY IN: } & \multirow[b]{2}{*}{ TABLE 6} \\
\hline & & TABLE 3 & TABLE 4 & \\
\hline 5,1 & $\begin{array}{l}\text { Land Ownership } \\
\text { Distribution }\end{array}$ & $\begin{array}{l}\text { Land ownership distri- } \\
\text { bution between federal, } \\
\text { state and private }\end{array}$ & $\begin{array}{l}\text { Land requirements for } \\
\text { industry using geo- } \\
\text { thermal energy }\end{array}$ & $\begin{array}{l}\text { Any major land } \\
\text { aggregation required }\end{array}$ \\
\hline 5,2 & Land Use & $\begin{array}{l}\text { Distribution of land } \\
\text { between recreational, } \\
\text { residential, cropland } \\
\text { and woodland, etc. }\end{array}$ & $\begin{array}{l}\text { Land use classifica- } \\
\text { tions required }\end{array}$ & $\begin{array}{l}\text { Any modifications } \\
\text { in land use required }\end{array}$ \\
\hline 3 & $\begin{array}{l}\text { Mineral } \\
\text { Exploration } \\
\text { Leases }\end{array}$ & $\begin{array}{l}\text { All present leases for } \\
\text { mineral exploration }\end{array}$ & Required leases & Action required \\
\hline 1 & Temperature & $\begin{array}{l}\text { Degree-Days Heating } \\
\text { Degree-Days Cooling }\end{array}$ & $\begin{array}{l}\text { Any special climate } \\
\text { control requirements }\end{array}$ & $\begin{array}{l}\text { Sultability of temp- } \\
\text { erature for process } \\
\text { as well as for human } \\
\text { comfort }\end{array}$ \\
\hline 2 & $\begin{array}{l}\text { Average } \\
\text { Wind }\end{array}$ & $\begin{array}{l}\text { Actual weather data } \\
\text { on wind }\end{array}$ & $\begin{array}{l}\text { Any special require- } \\
\text { ments for wind }\end{array}$ & $\begin{array}{l}\text { Suitability of wind } \\
\text { for process as well } \\
\text { as for human comfort }\end{array}$ \\
\hline 3 & $\begin{array}{l}\text { Average } \\
\text { Rain }\end{array}$ & $\begin{array}{l}\text { Actual weather data } \\
\text { on rain }\end{array}$ & $\begin{array}{l}\text { Any special rain } \\
\text { requirements }\end{array}$ & $\begin{array}{l}\text { Sultability of rain } \\
\text { for process as well } \\
\text { as for human comfort }\end{array}$ \\
\hline
\end{tabular}


TABLE 5 (Cont'd)

EXPLANATION OF ENTRY IN:

ENTRY CHARACTERISTIC

TABLE 3 TABLE 4

TABLE 6

\section{7,1 Hydrologic} Profile

7,2 Air Quality

7,3 Solid Waste

$\stackrel{\omega}{\omega}$
Actual hydrologic pro-

file and effluent restrictions

Actual Air Quality

Profile and possible

restrictions

Solid Waste disposal sites avallable

7,4 Seismic Activity
Previous occurence and severity of seismic activity in region
Water requirements and effluents produced

Process atr emissions

Type and Quantity of solid waste produced if any

Estimate of effect of reinfection if contemplated otherwise estimate of effect of reservoir depletion
Required modifications to process output/ or hydrologic profile

Required modifications to process output/ or Afr Quality

Disposition of solid waste

Recommended action to minimize possible damage to $11 \mathrm{fe}$ or property.

\section{8,1 Transporta- tion}

\section{8,2 Industrial Products \\ Center}

$\begin{aligned} 8,3 & \begin{array}{l}\text { Commercial } \\ \text { Products } \\ \text { Center }\end{array}\end{aligned}$

Present transportation system seving area including land, seas, and air

Proximity of industrial products market

Proximity of commercial Products market
Transporation requirements

Market distance restrictions of industry

Distance restrictions or product transportation
Required modifications in the transportation system if any

Required action to satisfy restrictions

Required action to satisfy restrictions 
TABLE 5 (Cont'd)

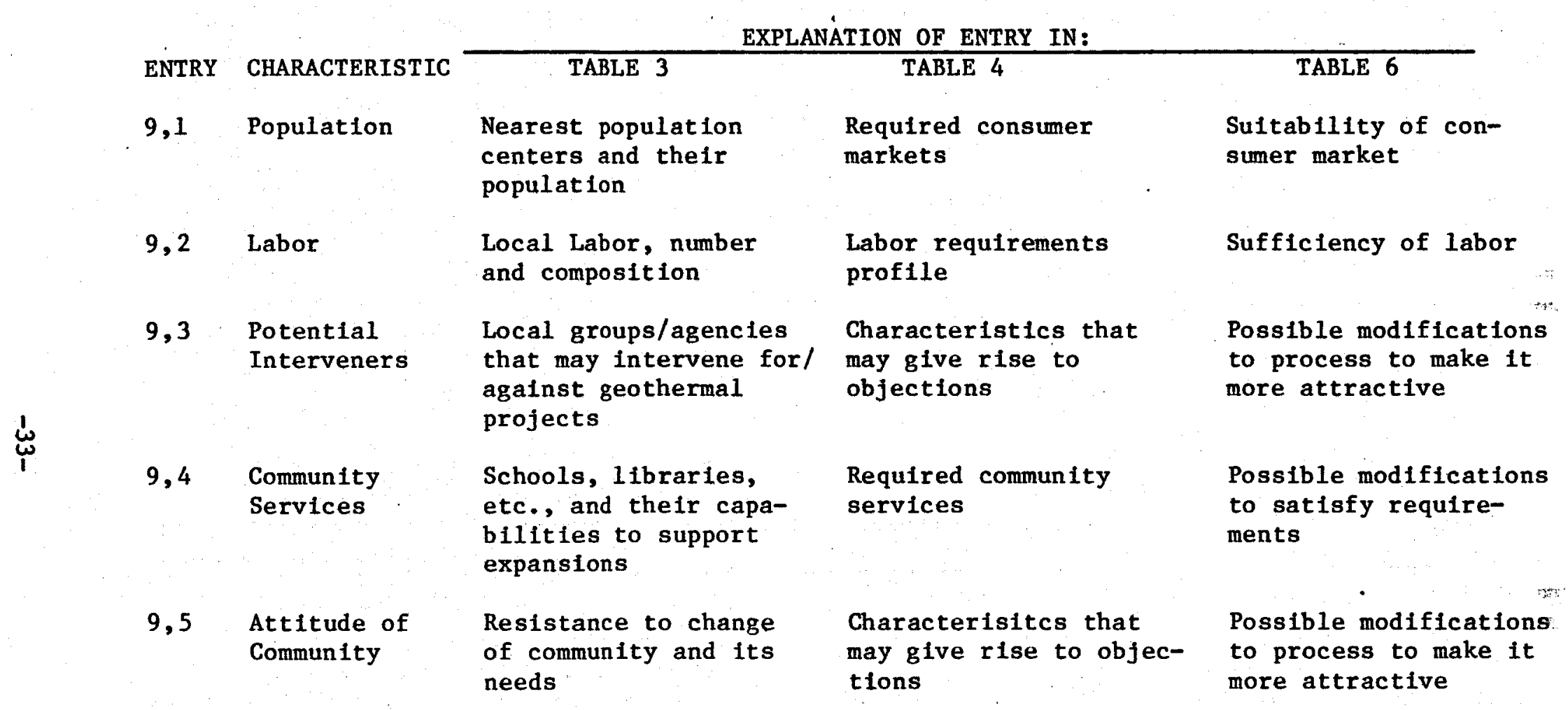


TABLE 5 (Cont'd)

\begin{tabular}{|c|c|c|c|c|}
\hline \multirow[b]{2}{*}{ ENTRY } & \multirow[b]{2}{*}{ CHARACTERISTIC } & \multicolumn{2}{|c|}{ EXPLANATION OF ENTRY IN: } & \\
\hline & & TABLE 3 & TABLE 4 & TABLE 6 \\
\hline 10,1 & $\begin{array}{l}\text { Regulations, } \\
\text { Laws, Statutes }\end{array}$ & $\begin{array}{l}\text { The regulations, laws } \\
\text { and statutes covering } \\
\text { geothermal development }\end{array}$ & $\begin{array}{l}\text { Process characteri- } \\
\text { stics that may conflict } \\
\text { with regulations }\end{array}$ & $\begin{array}{l}\text { Possible modifications } \\
\text { to process/or regula- } \\
\text { tions to make them } \\
\text { compatible }\end{array}$ \\
\hline 11,1 & $\begin{array}{l}\text { Financial } \\
\text { Institutions }\end{array}$ & $\begin{array}{l}\text { Financial institutions } \\
\text { that may be willing to } \\
\text { invest in project }\end{array}$ & $\begin{array}{l}\text { Approximate required } \\
\text { funding }\end{array}$ & $\begin{array}{l}\text { Need for government } \\
\text { funding }\end{array}$ \\
\hline
\end{tabular}

Need for government

funding

Possible modifications

o process/or regula-

tions to make them

stics that may conflic 


\begin{tabular}{|c|c|c|c|c|c|c|}
\hline$\cdots$ & \multicolumn{4}{|c|}{$\begin{array}{c}\text { TABLE } 6 \\
\text { SITE TRANSFORMATION }\end{array}$} & \multicolumn{2}{|l|}{$\begin{array}{l}\text { RESERvoIn: } \\
\text { moustrit: }\end{array}$} \\
\hline \multirow{2}{*}{ 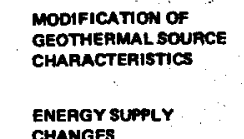 } & $\begin{array}{l}\text { MEAT } \\
\text { CoOL }\end{array}$ & PUMPOTn & $\begin{array}{l}\text { DESALINIZE } \\
\text { O.K. }\end{array}$ & $\begin{array}{l}\text { PRESSSUR(ZE } \\
\text { EXPAND (FLASH) }\end{array}$ & - & - \\
\hline & $\begin{array}{l}\text { AS S I } \\
\text { DECREASE }\end{array}$ & $\begin{array}{l}\text { AS I } \\
\text { DECREASE OTHER FUELS }\end{array}$ & $\begin{array}{l}\text { As is } \\
\text { MODIFY }\end{array}$ & $\begin{array}{l}\text { RELAAEILITY } \\
\text { NNCREASED/OECREASED }\end{array}$ & $\longrightarrow$ & $\begin{array}{l}\text { GEDTHERMAL FLUID } \\
\text { TRANSMISSION }\end{array}$ \\
\hline INOUSTRY CHANGES & $\begin{array}{l}\text { RELATED DOUST. } \\
\text { REOUNEED }\end{array}$ & - & - & - & - & - \\
\hline $\begin{array}{l}\text { NEW LOCALARAW } \\
\text { MATERIALS USED }\end{array}$ & $\begin{array}{l}\text { Expand Production } \\
\text { OKA AS is }\end{array}$ & $\begin{array}{l}\text { EXPAND PRODUCTION } \\
\text { OK AS IS }\end{array}$ & $\begin{array}{l}\text { EXPANO ProOUCTION } \\
\text { OKAS IS }\end{array}$ & - & - & - \\
\hline $\begin{array}{l}\text { LAND USE } \\
\text { MODIFICATONS }\end{array}$ & $\begin{array}{l}\text { MODIFY } \\
\text { OK AS IS }\end{array}$ & $\begin{array}{l}\text { MOOIFY } \\
\text { OK AS IS }\end{array}$ & ACTTON REQUIRED & - & - & - \\
\hline $\begin{array}{l}\text { CLMANE } \\
\text { SUTAABLITY }\end{array}$ & SUITABLLIT & SUITABLITS & SUTtaBatLT & - & - & - \\
\hline $\begin{array}{l}\text { ENVIRONMENTAL } \\
\text { IMPACT }\end{array}$ & MODificantions & MODIFICATIONS & DISPOSITION Of SOL.POLL. & $\begin{array}{l}\text { ACTION REQUNRED TO } \\
\text { MANIMMZE QAMAGE }\end{array}$ & - & - \\
\hline $\begin{array}{l}\text { TRANSPORTATIOA } \\
\text { CHANGE }\end{array}$ & $\begin{array}{l}\text { EXPAND } \\
\text { OKAS IS }\end{array}$ & REQUIRED ACTION & REOUIRED ACTION & - & - & - \\
\hline $\begin{array}{l}\text { DEMOGAAPHIC } \\
\text { SUITABLLTTY }\end{array}$ & $\begin{array}{l}\text { SUTAABLLTY OF CONSUMER } \\
\text { MARKET }\end{array}$ & $\begin{array}{l}\text { SUFFACEENCY OF } \\
\text { LOCAL LABOR }\end{array}$ & $\begin{array}{l}\text { POSSBBLE MODIFICATIONS } \\
\text { TO PROCESS }\end{array}$ & $\begin{array}{l}\text { POSS18LE MODFFCATIONB } \\
\text { TOPROCESS }\end{array}$ & \begin{tabular}{|l|} 
POSSB18L MODIF FAATIONS \\
TO PROCESS
\end{tabular} & - \\
\hline $\begin{array}{l}\text { INSTITUMONAL } \\
\text { CHANGE }\end{array}$ & $\begin{array}{l}\text { POSSIBLE MODAFICATIONS } \\
\text { TO MROCESS/REGU ATIONS }\end{array}$ & - & - & - & - & - \\
\hline 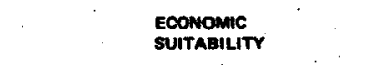 & $\begin{array}{l}\text { GOVT.STT. REOUIRED } \\
\text { Oo AS IS }\end{array}$ & - & - & - & - & - \\
\hline
\end{tabular}


the site-specific industry information may be obtained from the generic industry information with slight modifications.

Once both sets of data are developed, the next step is to analyze the Table 3 site characteristics in light of the Table 4 industry requirements. In general, it is expected that differences will be observed: the site characteristics will not meet all of the industrial requirements.* These differences will yield a new set of site/reservolr deficiency data. These data may similarly be arranged in tabular form of the same dimension and element location as Tables 3 and 4 (see Table 6, Site Transformation Table). The elements of the latter, if applied to the site characteristics table, should transform it to satisfy the specific industrial requirements being analyzed. The entries in Table 6 have also been defined in more detail in Table 5.

Using these three descriptive tabulations (Tables 3, 4 and 6) an evaluation scheme which assessess the potential for retrofitting existing industry, and for attracting new industry, may be developed and exercised. Appendix B presents a preliminary scoring method for use with the above-described data. The method presented therein has not yet been tested with actual site and industrial requirement data, as the latter have not been available. It is likely that the *It should be noted that several of the entries in the site characteristics table do not have comparable entries in the industrial requirements table. These site description factors represent general regional attributes which may enhance or retard geothermal development. The scoring procedure discussed in Appendix $B$ deals with these factors directly rather than through this industrial requirements comparison procedure. 
preliminary method presented in Appendix B will be refined as it is put into application; however, it is also expected that the bas is of the wethod--first-order Iinear combination of objective functions-will remain a useful paradigm. 
SECTION 4

METHODOLOGY FOR RANKING OF INDUSTRIES

There are a large number of Industrial processes that may be converted to the use of geothermal energy. A screening method to rank order these Industries in non-electric applications is presented in this section. The basis for the ranking is the impact that conversion to geothermal use of those industries will have on national energy demand. A score is given to each industry based on relative energy consumption of the industry, its present size in states possessing geothermal resources, and the amount of geothermal energy that state possesses. (As near-term payoff is being emphasized in this paper, the resource data used are limited to hydrothermal.) The score is then given by: Score for Industry $\mathrm{j}=\sum \frac{\text { Annual energy consumed in Industry } f}{\text { Total U.S. Industrial energy consumption }} \times 100$

$x$ Size of industry 1 in state $1 \times 100$ Total U.S. size of Industry $j$

$x$ Size of geothermal reserves in state $1 \times 100$ Total U.S. geothermal reserves

\section{Discussion of Industry Ranking}

The factors selected for the generation of a score for each industry are a gross indication of the upper bound of geothermal energy use by a given industry. 
Energy Consumption of the Industry. If the energy requirements of the Industry are small, then even if all the establishments of that type are converted to geothermal energy use in the U. S., the effect on energy consumption would be negligible. As with the Stage I screening method, this procedure will err toward higher scores in that it makes no allowance for those cases in which the energy requirements of the industry may not be fulfilled by the low-temperature heat that is characteristic of many geothermal resources. To Improve this situation, after rank ordering industries using this method, additional screening information may be obtained from the few industry engineering studies which have already been carried out. Relative Size of Industry in a State. Inherent In the use of this factor is the assumption that gross industry redistributions will not occur. It is not expected that the applicability of geothermal energy to certain processes w111 have a large impact on the distribution of industries in the U. S., at least not in the near future. If shifts of industry to states with geothermal reserves can be forecast, then a more approprlate factor in this case would be based on the projected size of the industry in the state as a percentage of the national size of that industry.

Relative Size of Geothermal Reserves in the State. Inherent in this factor is the assumption that the present assessment of $\mathrm{U}$. S. hydrothermal reserves $^{(2)}$ is reasonably accurate and that relative distribution among the states will not change drastically. 
As mentioned above, this paper considers only hydrothermal reserves. But as the technology for the use of other types of geothermal resources (such as geopressured and hot dry rock) becomes available, this factor will change greatly. .

Finally, in the generation of the scores the ranking was assumed to depend on the first power of the three factors discussed above. However, as some of the data become available, it may be necessary to alter this scoring procedure to redistribute the emphasis among those factors.

Example of Industry Ranking

To illustrate the procedure, ratings are performed for some of the industries that may be converted to geothermal energy, according to presently available studies. To facilitate data gathering, the classifications chosen are quite broad; however, the trends shown do point to possibilities for future studies. The industries are 1 isted in Table 7 together with their SIC ${ }^{(3)}$ codes. Industries with two-digit SIC codes are listed with others having three-digit SIC codes. The energy consumption of these industries and its percent of total U. S. industrial energy consumption is shown for each industry in the table. In Table 8, the distribution of hydrothermal reserves by state in the temperature range of $90^{\circ}$ to $150^{\circ} \mathrm{C}$ (the range usually considered for non-electric applications) is shown. In case of these reserves, the reservior size is usually between $0.2 \times 10^{18}$ and $10 \times 10^{18}$ calories. However, there are two reservoirs, one with estimated heat content of $263 \times 10^{18}$ 
TABLE 7

TOTAL U. S. ENERGY CONSUMPTION OF SELECTED INDUSTRIES

\author{
INDUSTRY TYPE AND \\ SIC CODE \\ Canned, Cured \& Frozen \\ Foods \\ 205
}
Sugar 206
All Other Food and Kindred Products $20-(203+206)$
Paper \& Allied Products 26

Industrial Chemicals 281

Soap

284
Agricultural Chemicals 287
All Other Chemicals \&
Allied Products $28-(281+284-287)$

Petroleum \& Coal Products 29

\section{ENERGY CONSUMPTION}

IN $10^{9} \mathrm{KW}$ HR

38.7

38.7

223.2

385.4

579.2

15.6

24.0

195.4

466.9
5.08

1.0

1.0

5.8

10.0

15.06

.4

.62

12.14
PERCENT OF TOTAL

U.S. INDUSTRIAL

ENERGY CONSUMPTION 
TABLE 8

HYDROTHERMAL ENERGY DISTRIBUTION BY STATE

FOR $90-150^{\circ} \mathrm{C}$ TEMPERATURE RESERVOIRS

STATE

Alaska

Arizona

California

Colorado

Hawai i

Idaho

Montana

Nevada

New Mexico

Oregon

Utah

Washington

Wyoming
4.7

1.0

12.0

2.9

1.0

276.2

1.6

8.5

.8

33.4

1.2

.9

.4
9.1

1,9

23.3

5.6

1.9

$25.6(535.3) *$

3.1

16.5

1.5

$6.6(64.7) *$

2.3

1.7

.8

\section{$344.6 \times 10^{18} \mathrm{cal}$}

Less* $(263+30)-293$

$$
51.6 \times 10^{18} \mathrm{cal}
$$

* Single reservoirs with heat contents of $263 \times 10^{18}$ cal and $30 \times 10^{18}$ exist in Idaho and Oregon respectively. These were excluded from the calculation of the percentages for all states. They were reintroduced in the calculation of percentage for Idaho and Oregon only (numbers in parentheses). 
calories in Bruneau-Grandview, Idaho, and one with an estimated content of $30 \times 10^{18}$ calories in Klamath Falls, Oregon. Because of the unusual size of these reservoirs and the blas they will create in the data if included in the percentage calculations, they have been omitted from the calculation. If included, the percentages for Idaho and Oregon would be those shown in the parenthesis.

For the relative size of the industry in a state, the only data that could be found easily were those in the 1972 Census of Manufacturers $^{(3)}$. The employment figures contained therein were used to obtain the relative size of the industry. The resulting products of the three factors for each state and Industry are shown in Table 9. The sum of these products across each row gives a total score for that industry. This score, together with a normalized Index of importance, is shown in the last two columns of the table. When the two large reservoirs are included the Index is as shown in Table 10.

Tables 9 and 10 indicate that the chemical industries should receive the highest attention while soap and agricultural chemical industries appear to be of least Importance. Pulp and paper Industries also rank high in importance.

The above conclusions are based on only partial data. As studies progress and as more information is collected it is quite possible that other industries will emerge as leaders for consideration. 
TABLE
RELATIVE IMPORTANCE OF SELECTED INDUSTRIES IN STATES WITH GEOTHERMAL RESERVOIRS

\begin{tabular}{|c|c|c|c|c|c|c|c|c|c|c|c|c|c|c|c|}
\hline \multirow{2}{*}{$\underset{\text { CODE }}{\text { INDUSRYY \& SIC }}$} & \multirow[t]{2}{*}{ ALASTA } & \multirow[t]{2}{*}{ ARIzONA } & \multirow[t]{2}{*}{ CALIFORNU } & \multirow[t]{2}{*}{ COLORADO } & \multirow[t]{2}{*}{ HAwAII" } & \multirow[t]{2}{*}{ IDAHO } & \multirow[t]{2}{*}{ MONTANA } & \multirow[t]{2}{*}{ MEVADA } & \multirow[t]{2}{*}{ NEW MEXICO. } & \multirow{2}{*}{ orecons } & \multirow{2}{*}{ UTAH } & \multirow{2}{*}{ XASH IYGTOK } & \multirow{2}{*}{ wromave } & \multicolumn{2}{|c|}{ RELATIVE IMPORTANCE } \\
\hline & & & & & & & & & & & & & & SUM & DMDEX \\
\hline $\begin{array}{l}\text { Canned, cured \& Prozen Poods } \\
(205)\end{array}$ & 0 & .3 & 501 & 2.4 & 4. & $\begin{array}{r}25.6 \\
(535.3)\end{array}$ & o & 2.64 & 0 & $\begin{array}{r}25.7 \\
(252.3)\end{array}$ & .3 & 6.26 & 0 & $\begin{array}{r}568.2 \\
(1,304)\end{array}$ & $\begin{array}{l}16.5 \\
(8.2)\end{array}$ \\
\hline Sugar (206) & 0 & .34 & 223 & 13 & 6.72 & $(872)^{41.7}$ & 1.08 & 0 & 0 & $(45.3)$ & 1.72 & 2.21 & .28 & $(1,165)$ & $\begin{array}{l}8.6 \\
(7.3)\end{array}$ \\
\hline $\begin{array}{l}\text { N1 Other Food o Rindred } \\
\text { Product: } \\
20-(203+206)\end{array}$ & 0 & 5.51 & 1,039 & 47.73 & .55 & $\begin{array}{c}16 \\
(334)\end{array}$ & 4.52 & 7.66 & 2.73 & $(368)^{37.5}$ & 6.38 & 13.51 & .29 & $\begin{array}{l}1,181.38 \\
(1,830)\end{array}$ & $\begin{array}{r}34.3 \\
(11.5)\end{array}$ \\
\hline Paper \& N11ied Product: (26) & 24.6 & 2.7 & 1,258 & 16.8 & .6 & $\begin{array}{r}.99 \\
(20.8)\end{array}$ & 1.9 & 0 & 0 & (873): & 1.4 & 46.2 & 0 & $\begin{array}{c}1,463 \\
(2,246)\end{array}$ & $\begin{array}{l}42.5 \\
(14.1)\end{array}$ \\
\hline Industrial Chemicals (281) & 0 & 5.7 & 1,084 & 16.9 & 0 & $\begin{array}{r}678 \\
(14,186)\end{array}$ & 9.33 & 124 & 4.5 & $(370))^{37.7}$ & 6.9 & 97.3 & 0 & $(15,904)$ & $\begin{array}{c}60 \\
(100)\end{array}$ \\
\hline Soap Producte (284) & & .1 & 90.4 & .4 & .14 & 0 & 0 & 0 & 0 & 0 & .16 & 0 & 0 & 91.2 & 2.65 \\
\hline Agricultural Chenicals (287) & 0 & .47 & 93 & 2.7 & 0 & $(518)$ & o & 0 & 0 & 0 & 0 & .66 & 0 & $\begin{array}{c}121.6 \\
(614.8)\end{array}$ & $\begin{array}{l}(.6) \\
3.53 \\
(3.9)\end{array}$ \\
\hline $\begin{array}{l}\text { Al1 other Chemical Induatries } \\
28-(281+284+287)\end{array}$ & 0 & 4.62 & 571.70 & 5.38 & .3 & $\begin{array}{c}6.5 \\
(135.99)\end{array}$ & .46 & 4.22 & .25 & $\begin{array}{r}9.38 \\
(92.05)\end{array}$ & 1.98 & 2.44 & 0 & $\begin{array}{l}606.93 \\
(819)\end{array}$ & $\begin{array}{l}17.65 \\
(3.15)\end{array}$ \\
\hline Petroleum a cosl products (29) & 0 & 6.2 & 3,266 & 38.7 & 6.2 & 0 & 20.3 & 0 & 3.76 & $(415))^{42.3}$ & 15.78 & 31 & 8.98 & $(3,812)$ & $\begin{array}{l}100 \\
(24)\end{array}$ \\
\hline
\end{tabular}


TABLE 10

COMPARISON OF INDUSTRY INDEX WITH AND WITHOUT INCLUSION OF THE TWO LARGE HYDROTHERMAL RESERVOIRS IN IDAHO AND OREGON

\begin{tabular}{|c|c|c|}
\hline $\begin{array}{l}\text { INDUSTRY \& SIC } \\
\text { CODE }\end{array}$ & $\begin{array}{l}\text { INDEX EXCLUDING TWO } \\
\text { LARGE RESERVOIRS }\end{array}$ & $\begin{array}{l}\text { INDEX INCLUDI } \\
\text { LARGE RESERV }\end{array}$ \\
\hline $\begin{array}{l}\text { Canned, Cured \& } \\
\text { Frozen Foods } \\
205\end{array}$ & 16.5 & 8.2 \\
\hline${ }_{206}^{\text {Sugar }}$ & 8.6 & 7.3 \\
\hline $\begin{array}{l}\text { All other Food and } \\
\text { Kindred Products } \\
20-(203+206)\end{array}$ & 34.3 & 11.5 \\
\hline $\begin{array}{l}\text { Paper \& Allied } \\
\text { Products } \\
26\end{array}$ & 42.5 & 14.1 \\
\hline $\begin{array}{c}\text { Industrial Chemtcals } \\
\qquad 281\end{array}$ & 60 & 100 \\
\hline Soap 284 & 2.65 & .6 \\
\hline $\begin{array}{l}\text { Agricultural Chemicals } \\
\qquad 287\end{array}$ & 3.53 & 3.9 \\
\hline $\begin{array}{l}\text { Al1 Other Chemicals } \\
\text { \& Allied Products } \\
28-(281+284-287)\end{array}$ & 17.65 & 5.15 \\
\hline $\begin{array}{l}\text { Petroleum \& Coal } \\
\text { Products } \\
29\end{array}$ & 100 & 24 \\
\hline
\end{tabular}


As for the scores for Idaho and Oregon, it is important to determine the proximity of the industries to the large reservoirs. If it is found that all industries will be located adjacent to those reservoirs, then the larger percentages should be used. 
APPENDIX A

STAGE I RAW DATA

Append1x A provides supplementary Information for the Stage I geothermal site ranking methodology described in Section 2 . Included In Appendix $A$ are raw data collected in the preliminary data search for the sample sites indicated in Figure A-1. This information was primarily intended to determine what data are avallable for use in determining factors for the ranking of geothermal sites. Once the factors were chosen, the information used in ranking calculations was a subset of the raw data tables.

A list of Stage I factors that were finally derived and the raw data applied to each factor are summarized in Table A-1. Tables A-2 to A-10 contaln all the data collected for this study. In the future, ranking of additional geothermal sites would be more timeefficient if only Table A-1 data are collected. 


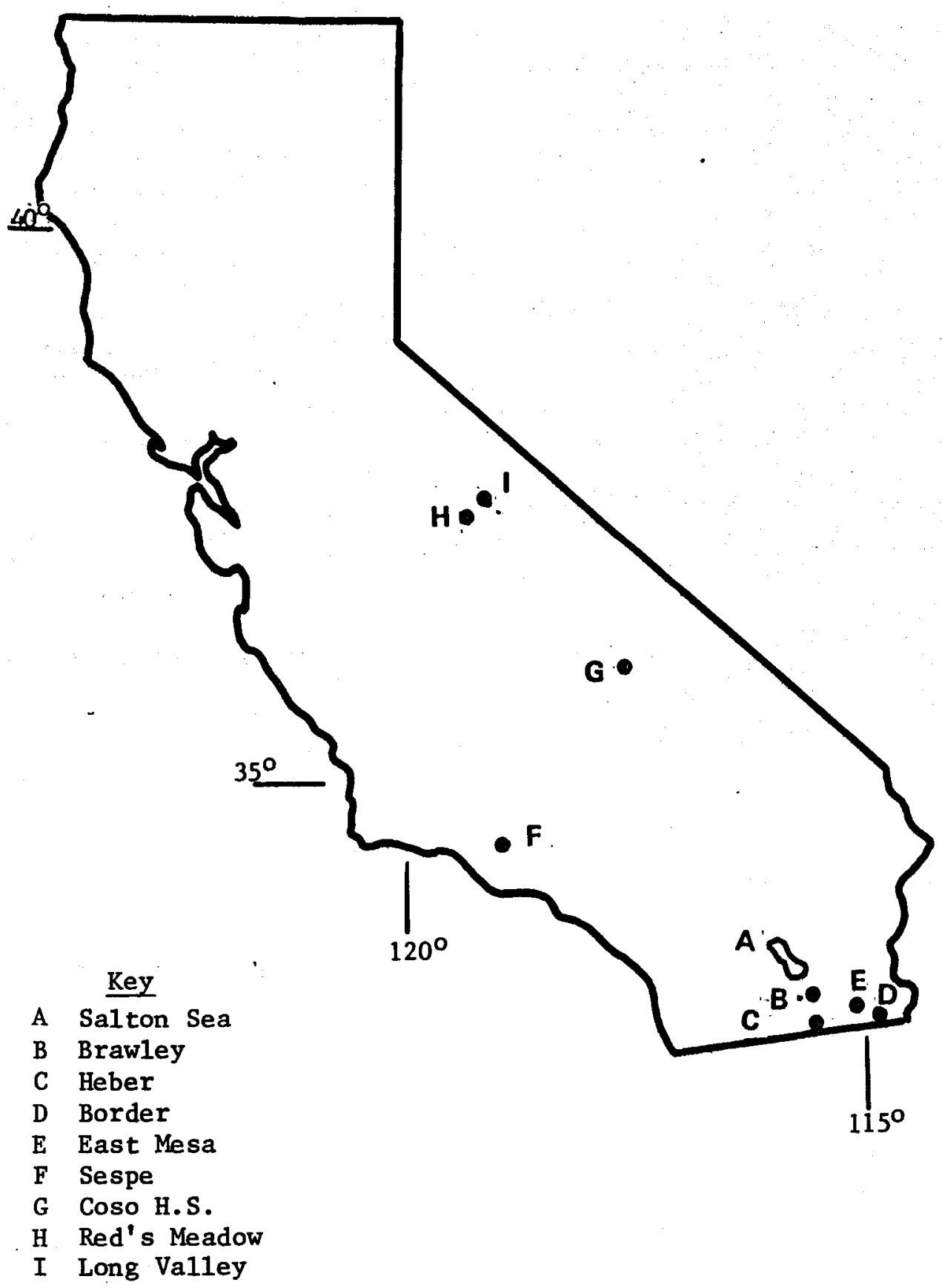

FIGURE A-1

CALIFORNIA STUDY SITES 
TABLE A-1

FACTORS CHOSEN AND RELEVANT DATA FROM RAW DATA TABLES

\section{Factor}

A. Reservoir Potential in Satisfying Existing Industry Energy Demands

B. Evidence of Existing Geothermal Development Activity

C. Space Heating Demand

D. Sultability of Water Resources

E. Space Cooling Demand
Table

A-4

A-7

A-8

A-9

A-10

A-9
Data from Table, Applied to Factor

Total Estimated Industrial Fuel 011 and Natural Gas Consumption by C1ty or Town Reservoir Assumptions: Heat Content

Energy and Utilities

Population and Heating Degree Days

Water Resources

Population and Cooling Degree Days 


\begin{tabular}{|c|c|c|c|c|c|}
\hline \multicolumn{6}{|c|}{$\begin{array}{l}\text { TABLE A-2 } \\
\text { LAND USE }\end{array}$} \\
\hline & GENERAL DESCRIPTION & PUBLICLY OWNED LAND & CROPLAND & FOREST AND WOODLAND & TRANSPORTATION \\
\hline Salton Sea & $\begin{array}{l}\text { Desert shrubland mostly un- } \\
\text { grazed E. and SW of Sea. } \\
\text { Irr19ated N..W. and S.E. } \\
\text { Desert shrubland grazed to } \\
\text { west. Salton Sea: primar11y } \\
\text { recreation area, many water } \\
\text { gports. }\end{array}$ & $\begin{array}{l}\text { E1 Centro Naval Factlity E. } \\
\text { of Sea. National W11d11fe } \\
\text { s. of Sea. Scattered Ped- } \\
\text { eraily owned tracts 25-50z } \\
\text { den sity and 50-100\% density. }\end{array}$ & 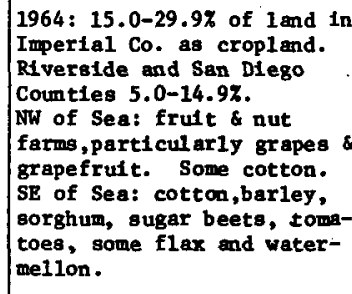 & $\begin{array}{l}\text { Imperial co: } 0-4.9 \% \text { forest } \\
\text { and woodland. } \\
\text { Riverside o San Diego co. } \\
5.0-14.97 \text {. } \\
\text { Nothlng in close proximt ty } \\
\text { to the sea. }\end{array}$ & $\begin{array}{l}\text { Coachella canal E. of sea. } \\
\text { southera Pac1fic RR E. and } \\
\text { S. of } 3 \text { sea. }\end{array}$ \\
\hline $\begin{array}{l}\text { Brawley, } \\
\text { Heber, } \\
\text { Border, } \\
\text { East Mesa }\end{array}$ & Irrigated 1and. Imperial co. & See Above & See "SE of Sea" above & $\begin{array}{l}\text { See "Impert al co." above. } \\
\text { No forest of woodland in 1m- } \\
\text { mediate area. }\end{array}$ & 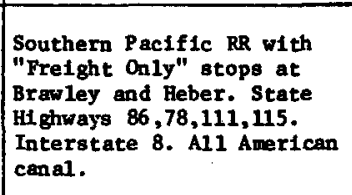 \\
\hline Sespe, н.S. & 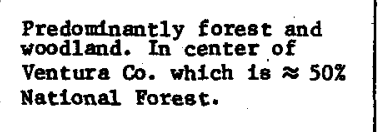 & $\begin{array}{l}\text { Los Padres Nattonal Forest, } \\
\text { Angeles National Forest in } \\
\text { area. }\end{array}$ & $\begin{array}{l}\text { Ventura Co. : 5-14.9\% crop- } \\
\text { ant. No o outstanding croop } \\
\text { in area (primartily live- } \\
\text { stock and dalry). }\end{array}$ & $\begin{array}{l}\text { More than } 75 \% \text { of county is } \\
\text { forest \& woodland,15-29.9\%. } \\
\text { of 1and for grazing. }\end{array}$ & $\begin{array}{l}\text { Southem Pactfic RR, freight } \\
\text { only. }\end{array}$ \\
\hline Cosо н.s. & $\begin{array}{l}\text { In Inyo co., } \approx 15 \text { mi s. of } \\
\text { Owens Lake, } 2 \text { mit E. of Tulare } \\
\text { co. 11ne. Predominant1y } \\
\text { forest \& woodland mosty un- } \\
\text { grazed. Desert ghrubland } \\
\text { grazed to E. No population. }\end{array}$ & 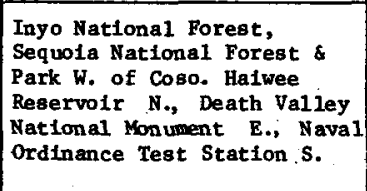 & $\begin{array}{l}\text { Inyo co: } 4.9 \mathrm{z} \text { and under for } \\
\text { croppland. } \\
\text { Tulare co: 15-29.9\%. } \\
\text { No predominant crops in } \\
\text { Coso area. }\end{array}$ & $\begin{array}{l}47 \text { and inder, forest } \& \text { wood- } \\
\text { land in Inyo ca. 50-74.92 in } \\
\text { Tulare co. }\end{array}$ & $\begin{array}{l}\text { Southem Pact fic RR, } \\
\text { Preight only. Los Angeles } \\
\text { Aqueduct in area. }\end{array}$ \\
\hline Red's Meadow & $\begin{array}{l}\text { At Mono/Madera county } \\
\text { 11nes, near Fresno Co. } \\
\text { In Inyo National Forest }\end{array}$ & \begin{tabular}{|l|} 
In Inyo National Po rest \\
adjacent to Sierra National \\
Forest.
\end{tabular} & $\begin{array}{l}\text { No eignificant crops in } \\
\text { area. }\end{array}$ & $\begin{array}{l}\text { Porest and Woodland (all } \\
\text { Nattona1) }\end{array}$ & \\
\hline Long Valley & $\begin{array}{l}\text { Mono Co., at Lake Crowley, } \\
\text { Surrounded by Inyo National } \\
\text { Forest. Approximately } 10 \mathrm{m1} \\
\text { B. of Red's Meadow }\end{array}$ & See "Red's Meadow," above & See "Red's Meadow," above & & 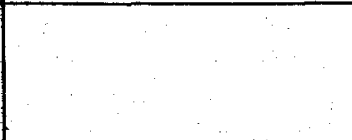 \\
\hline
\end{tabular}


TABLE A-3

BUSINESS AND INDUSTRY

(by City and Town)

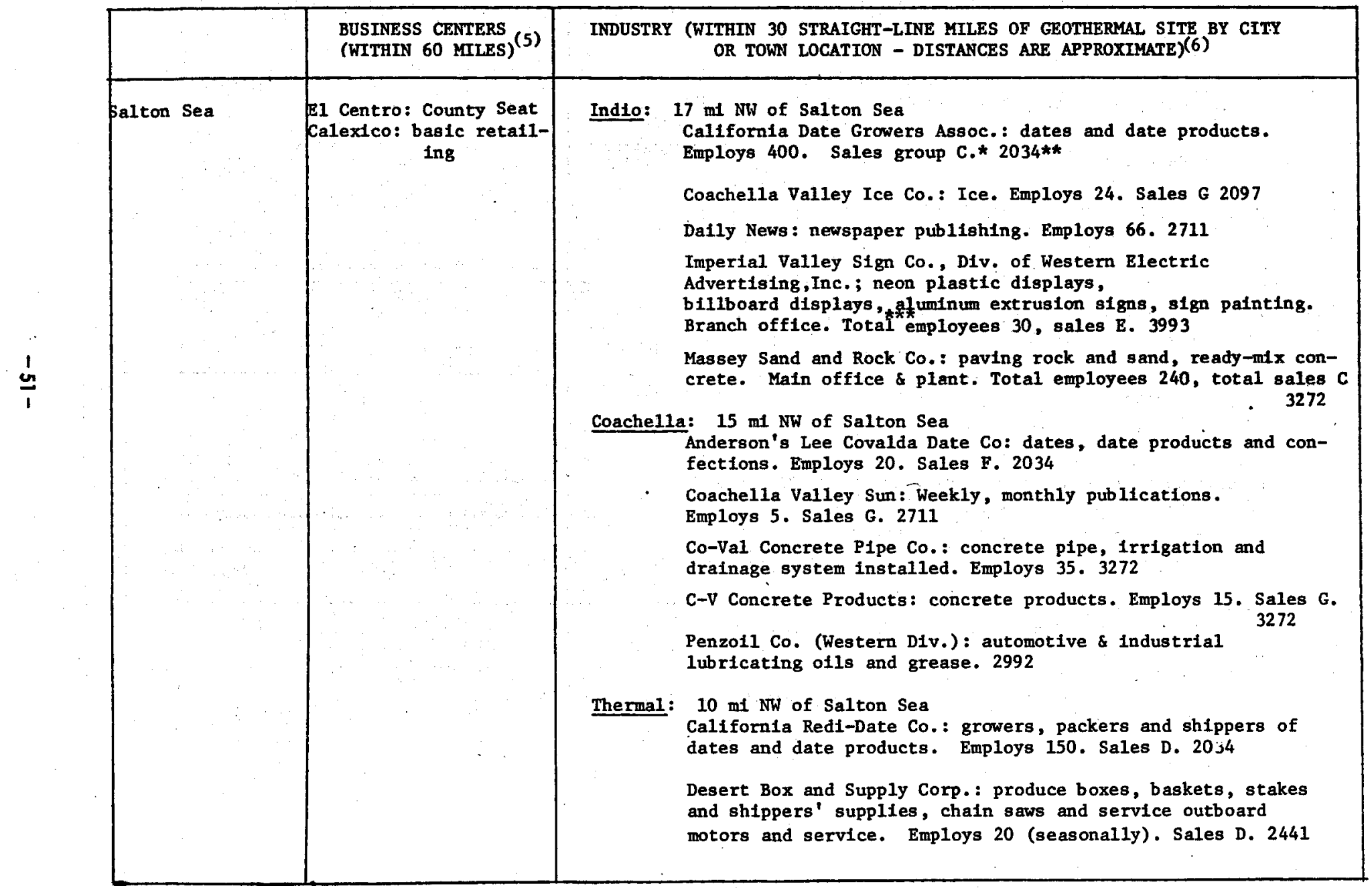




\section{TABLE A 3 (CONTINUED)}

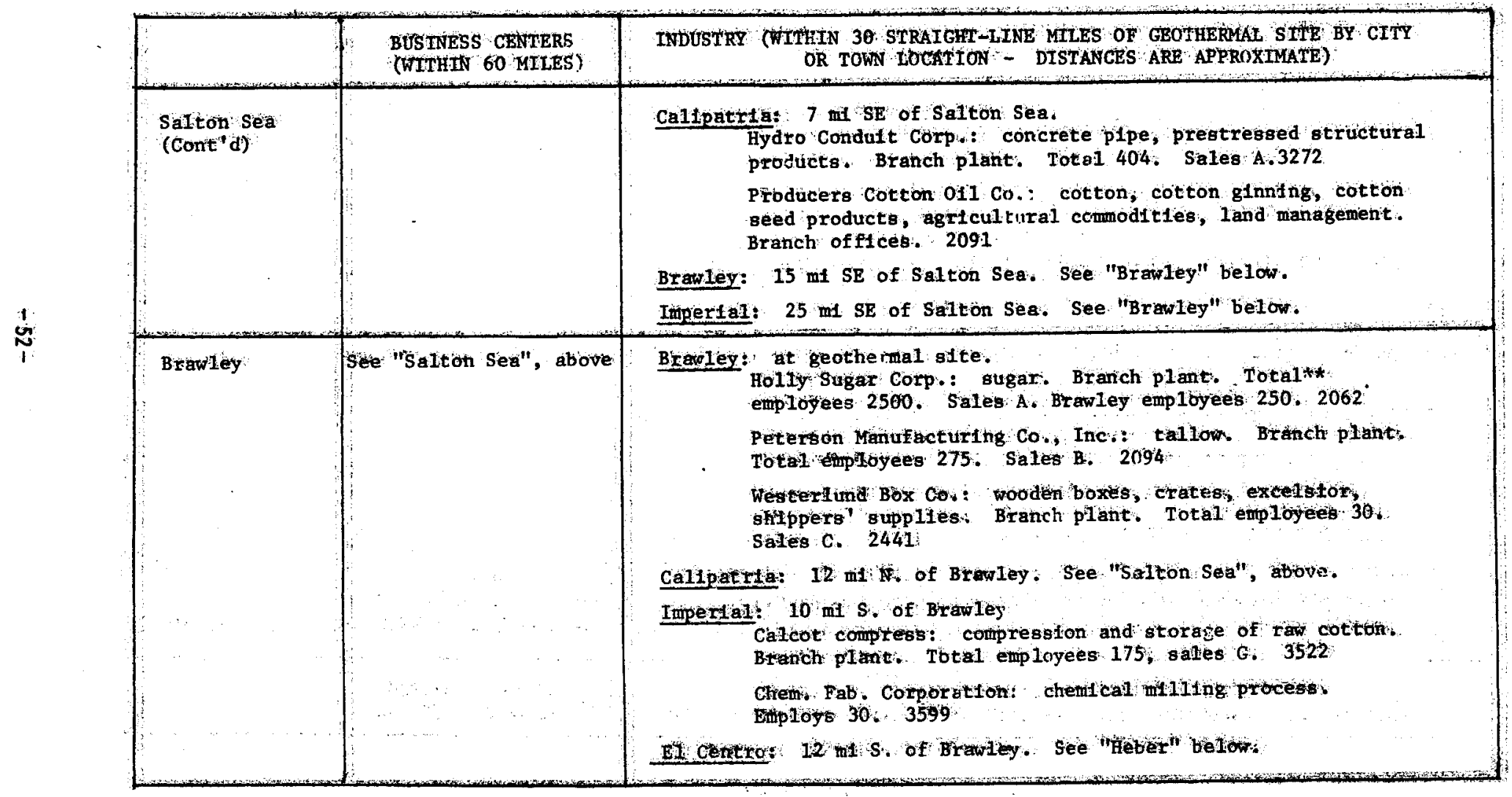

$\because \ldots, \cdots$ 


\section{TABLE A-3 (CONTINUED)}

\begin{tabular}{|c|c|c|}
\hline & $\begin{array}{l}\text { BUSINFSS CENTERS } \\
\text { (WITHIN } 60 \text { MILES) }\end{array}$ & $\begin{array}{l}\text { INDUSTRY (WITHIN } 30 \text { STRAIGRT-LINE MILES OF GEOTHERMAL STTE BY CITY } \\
\text { OR TOWN LOCATTON - DISTANCRS ARE APPROXIMATE) }\end{array}$ \\
\hline Heber & See "Salton Sea", above & 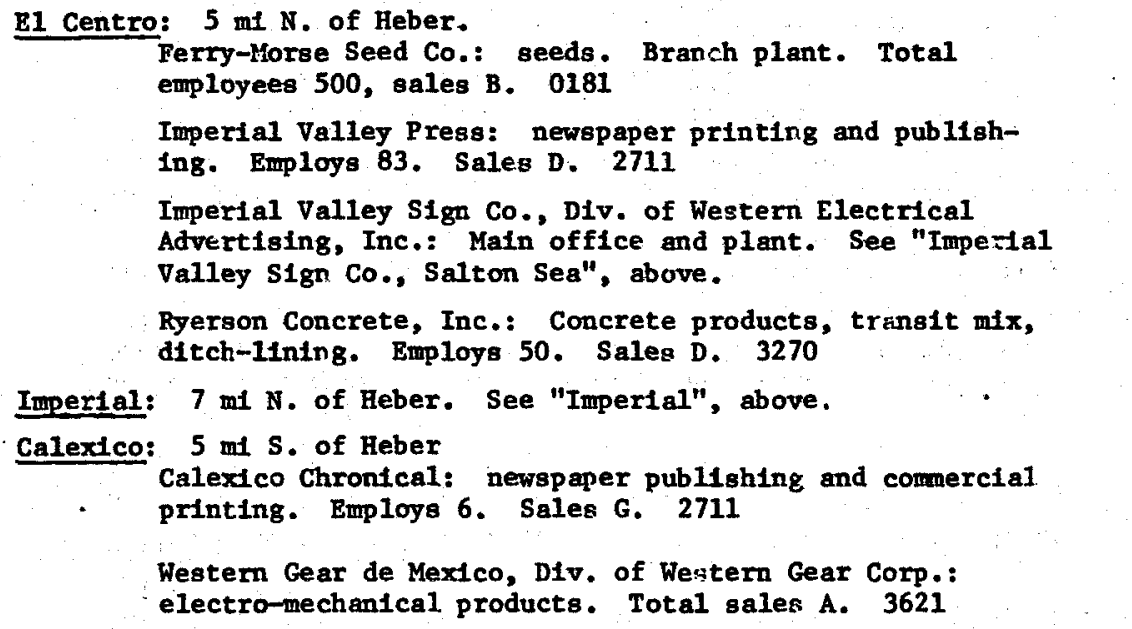 \\
\hline $\begin{array}{l}\text { East Mesa } \\
\text { and Border }\end{array}$ & See "Salton Sea,"above & $\begin{array}{l}\text { Brawley: } 25 \mathrm{ml} \mathrm{NW} \text { of E. Mesa. See "Brawley," above } \\
\text { Imperlal: } 20 \mathrm{ml} \text { NW of E. Mesa, } 27 \mathrm{mi} \text {. NW of Border. See "Imperial," } \\
\text { above. } \\
\text { E1 Centro: } 17 \mathrm{ml} \text { W. of E. Mesa, } 25 \mathrm{mi} \text {. NW of Border. }\end{array}$ \\
\hline
\end{tabular}




\section{TABLE ASTCONTINUED:}

\begin{tabular}{|c|c|c|}
\hline & 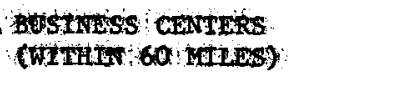 & 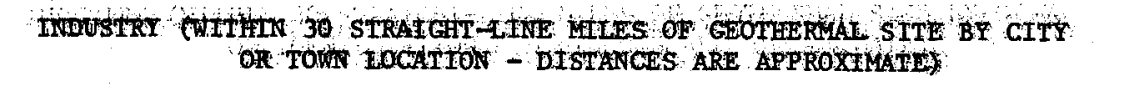 \\
\hline Sespe His. & 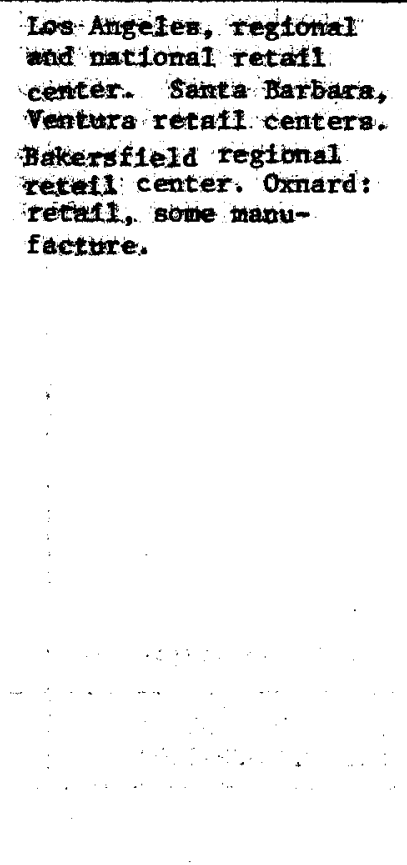 & 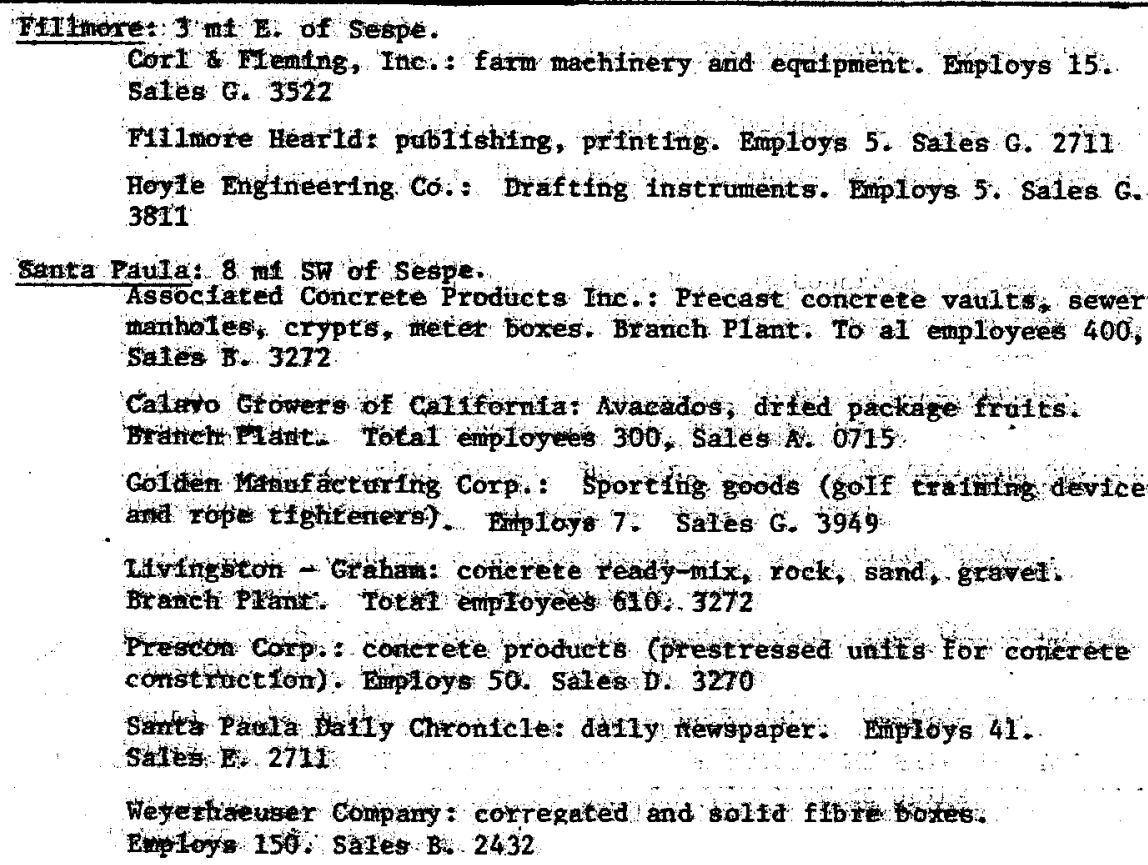 \\
\hline
\end{tabular}




\section{TABLE A-3 (CONTINUED)}

\begin{tabular}{|c|c|c|}
\hline & $\begin{array}{l}\text { BUSINESS CENTERS } \\
\text { (WTTHIN } 60 \text { MILES) }\end{array}$ & $\begin{array}{l}\text { INDUSTRY (WITHIN } 30 \text { STRAIGHT-LINE MILES OF GEOTHERMAL SITE BY CITY } \\
\text { OR TOWN LOCATION - DISTANCES ARE APPROXIMATE) }\end{array}$ \\
\hline $\begin{array}{l}\text { Sespe H.S. } \\
\text { (Cont'd) }\end{array}$ & & 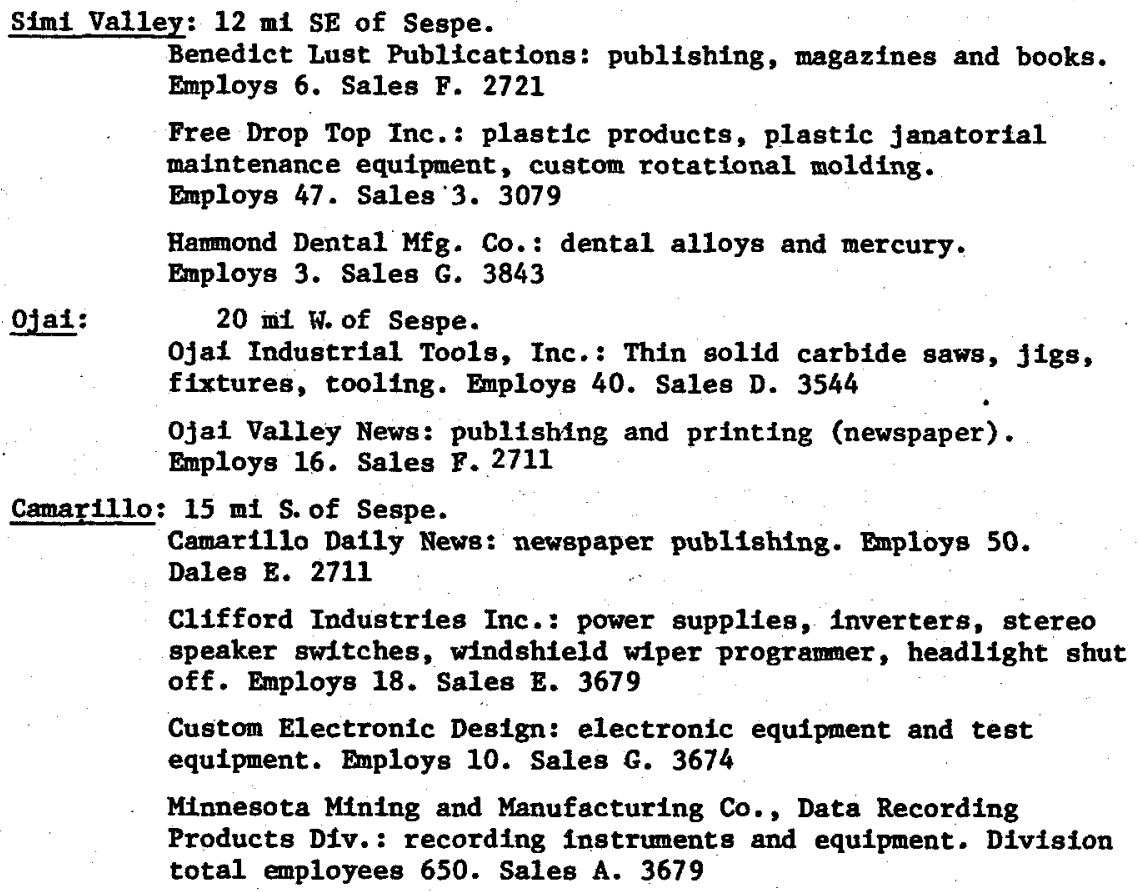 \\
\hline
\end{tabular}




\section{TABLE A-3 (CONTINUED)}

\begin{tabular}{|c|c|c|c|}
\hline \multirow{5}{*}{ I } & & $\begin{array}{l}\text { BUSFNESS CENTERS } \\
\text { (WITHIN } 60 \text { MTLES) }\end{array}$ & $\begin{array}{c}\text { INDUSTRY (WTTIIN } 30 \text { STRAFGHT-LINE MILES OF GEOTHERMAL STTE BY CTTY } \\
\text { OR TOWN LOCATION - DISTANCES ARE APPROXIMATE }\end{array}$ \\
\hline & $\begin{array}{l}\text { Sespe H.S. } \\
\text { (Cont!d) }\end{array}$ & & 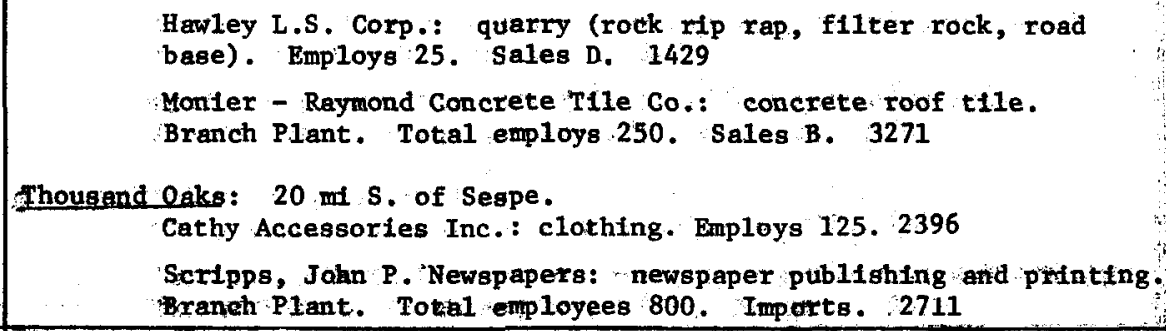 \\
\hline & Coso HeS. & $\begin{array}{l}\text { Hakersfleild: regional } \\
\text { retali canter. } \\
\text { Portem flle: retala- } \\
\text { Ing bustnees center }\end{array}$ & 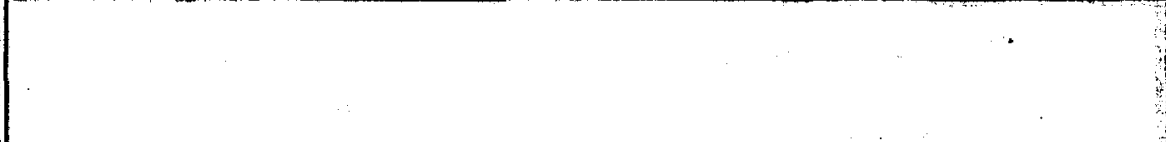 \\
\hline & Red's $\mathrm{s}$ & $\begin{array}{l}\text { Rresina: retatling } \\
\text { regional center. } \\
\text { Tanufacturing Center. }\end{array}$ & \\
\hline & $\begin{array}{l}\text { Long } \\
\text { Vatiley }\end{array}$ & $\begin{array}{l}\text { See "Red"s Meadow", } \\
\text { bove. }\end{array}$ & $\begin{array}{l}\text { Mamnoth Zakes: } 10-45 \mathrm{ml} \text { NW of long Valley. } \\
\text { Haddaway Mfg. L tured vibrator alr pump for Invest- } \\
\text { ments, aeration. Employs } 6.3561\end{array}$ \\
\hline
\end{tabular}

* Annul Gross Sales Code. Sales A $=$ over $\$ 25,000,000$; Sales B $=\$ 10-25,000,000 ; \$ a 1 e s$ C $=\$ 5-10, \$ 000 ; 000 ;$ Sales $D=\$ 1-5,000,000$; Sales $\mathrm{E}=\$ 500,000-1,000 ; 000$; Sales F $=\$ 250,000,000$; Sales G - tess than $\$ 250,000$

** U.S. Bureau of the Census, Standaxd Industrita1 code number.

*** "Tota1" Employees and Sales tepresents the sam of all branch of fices and plants. 



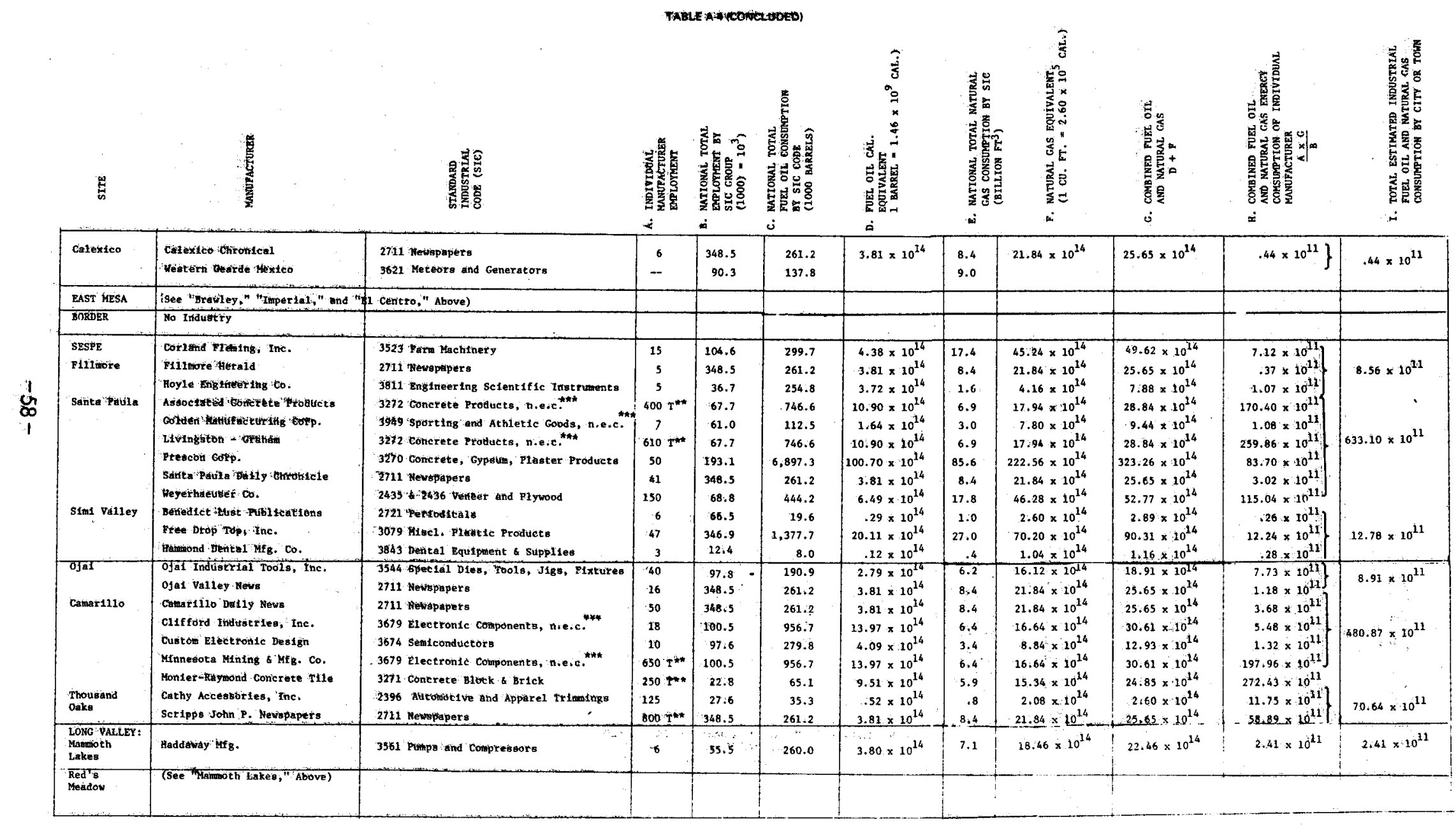

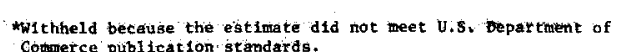

**rotal temployment for all branch plants and wain plant (where
data for Individuat plent 15 not readily avaitables)

***sct elsewhere classifled.

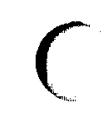




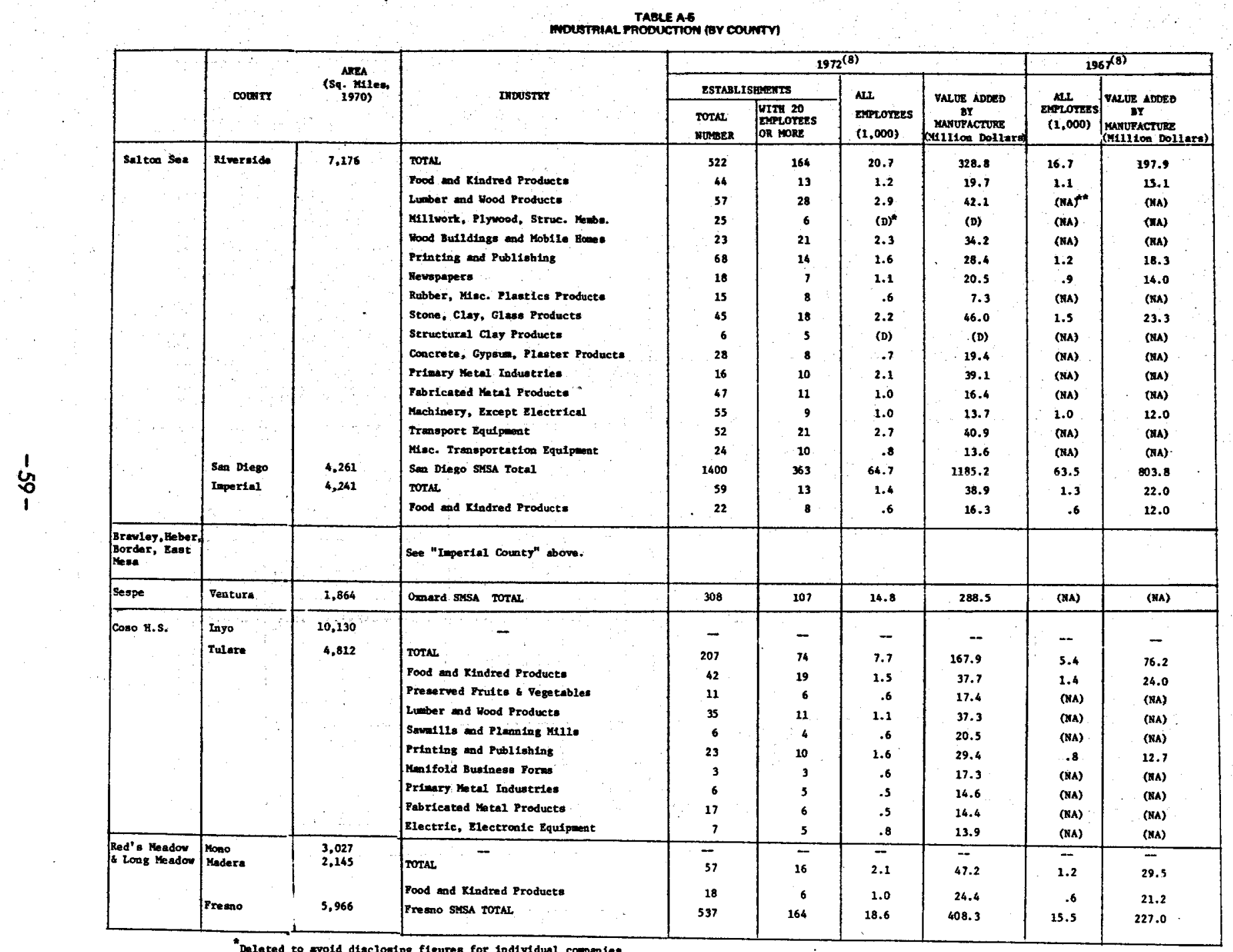

*** Doleted to evold disclooing figures for Lndividual compenses 
TABLE $A-6$

PETROEEUM AND NATUKAC GAS PRODUCTION (BI COUNTI)

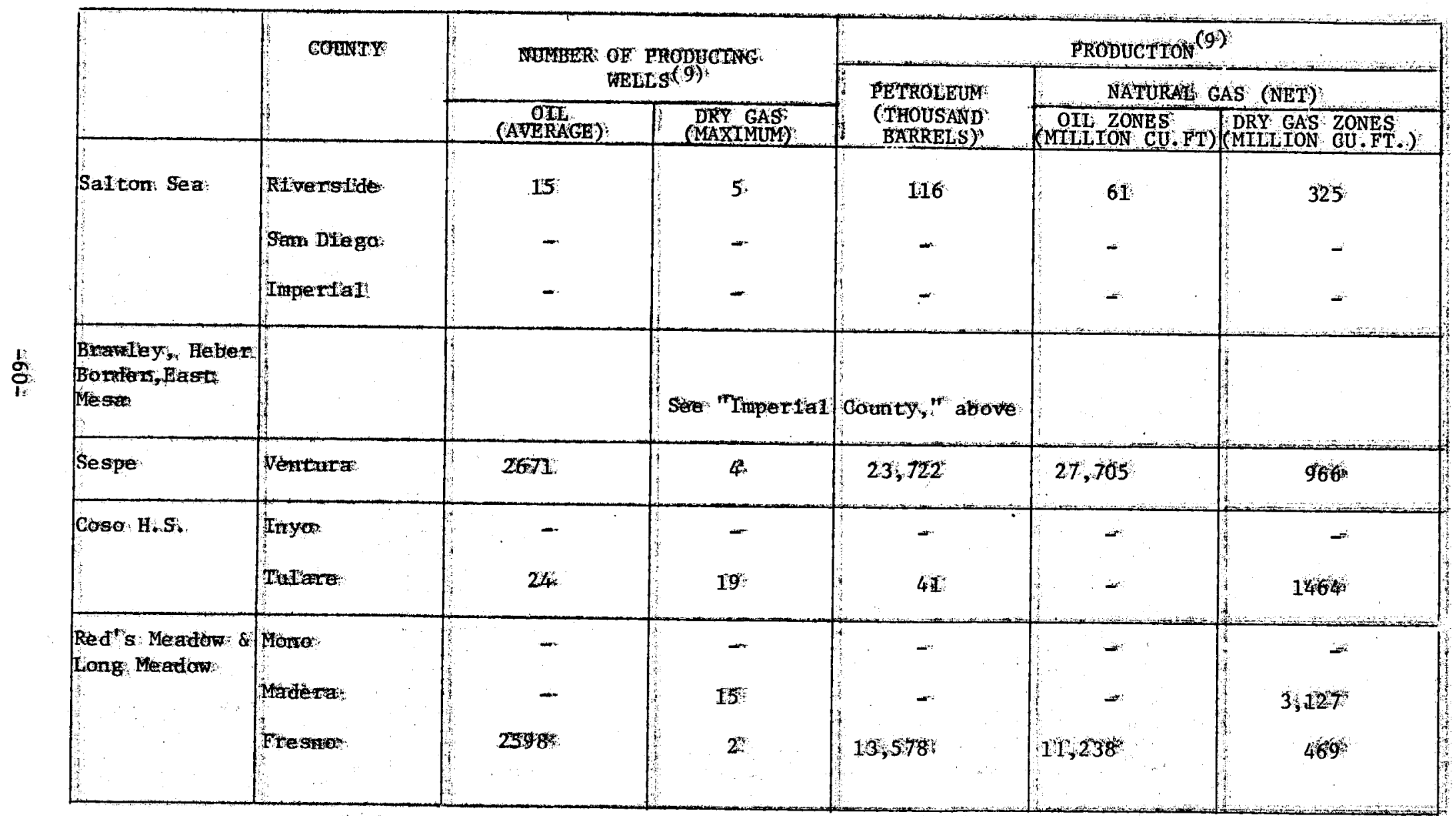




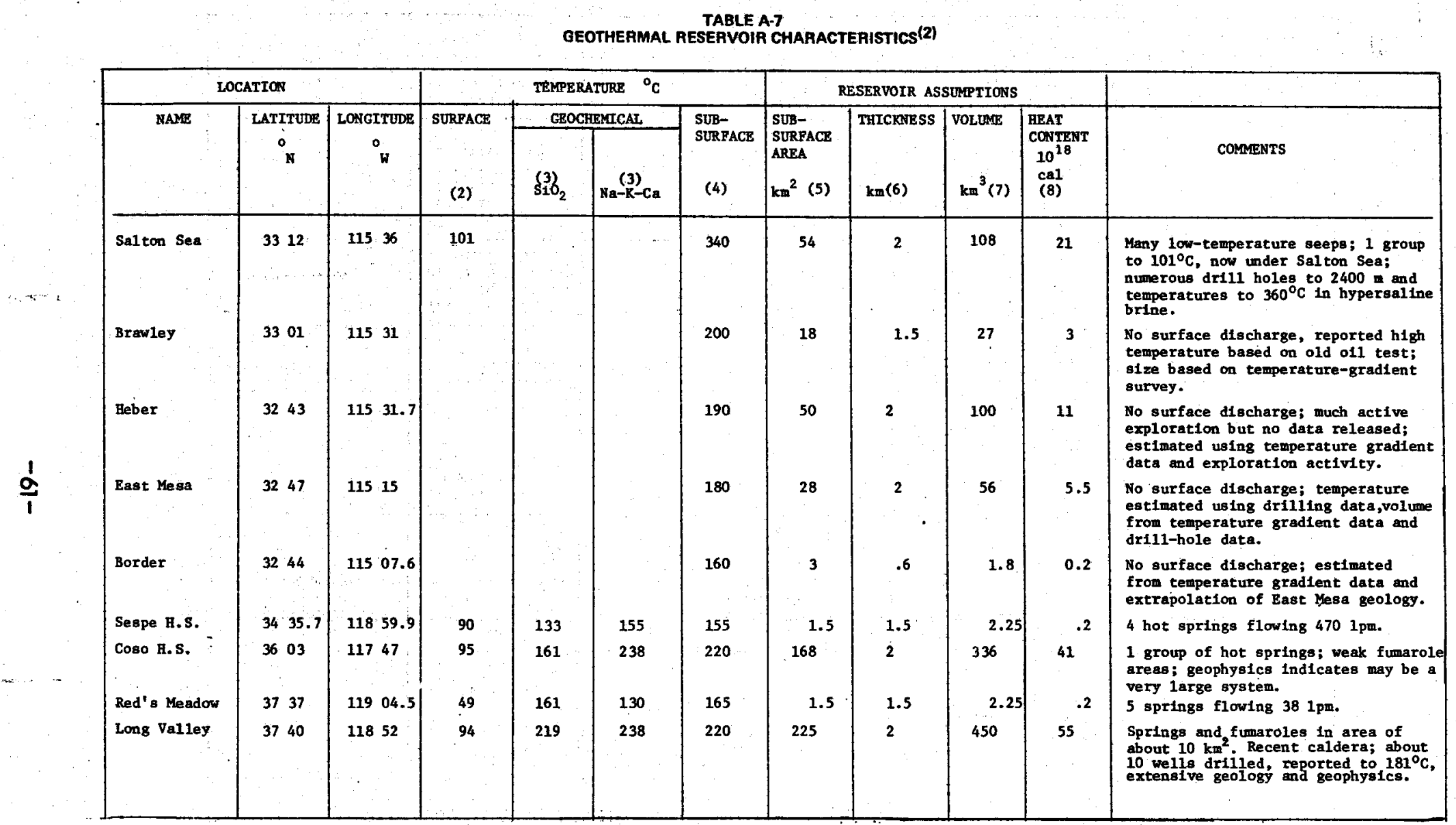

(1) Identifled Hot-Watex Convection Systeme with Indicated Subsurface Temperatures above $150^{\circ} \mathrm{C}$.

(3) Predicted using chemical geothernometers, assuming last equilibration in the reservoir; assumes saturation of $\mathrm{SLO}_{2}$ with respect to quartz,

and no loss of Ca from calcite deposition.

(5) From surface manifestations; geophys ical data, well records and geologic inference. Assumes $1.5 \mathrm{~km}^{2}$ if no data pertinent to size is available.

(6) Top assumed at depth of $1.5 \mathrm{~km}$ if no data avaliable. Bottom assumed at $3 \mathrm{~km}$ depth for all convection syatems.

(8) Calculated as product of assumed volume, volumetric specific heat of $0.6 \mathrm{cal} / \mathrm{cm}^{3}{ }^{\circ} \mathrm{C}$, and temperature in degrees $\mathrm{C}$ above $15^{\circ} \mathrm{C}$. 
TABLEAA:

ENEREY AND UTTITIES

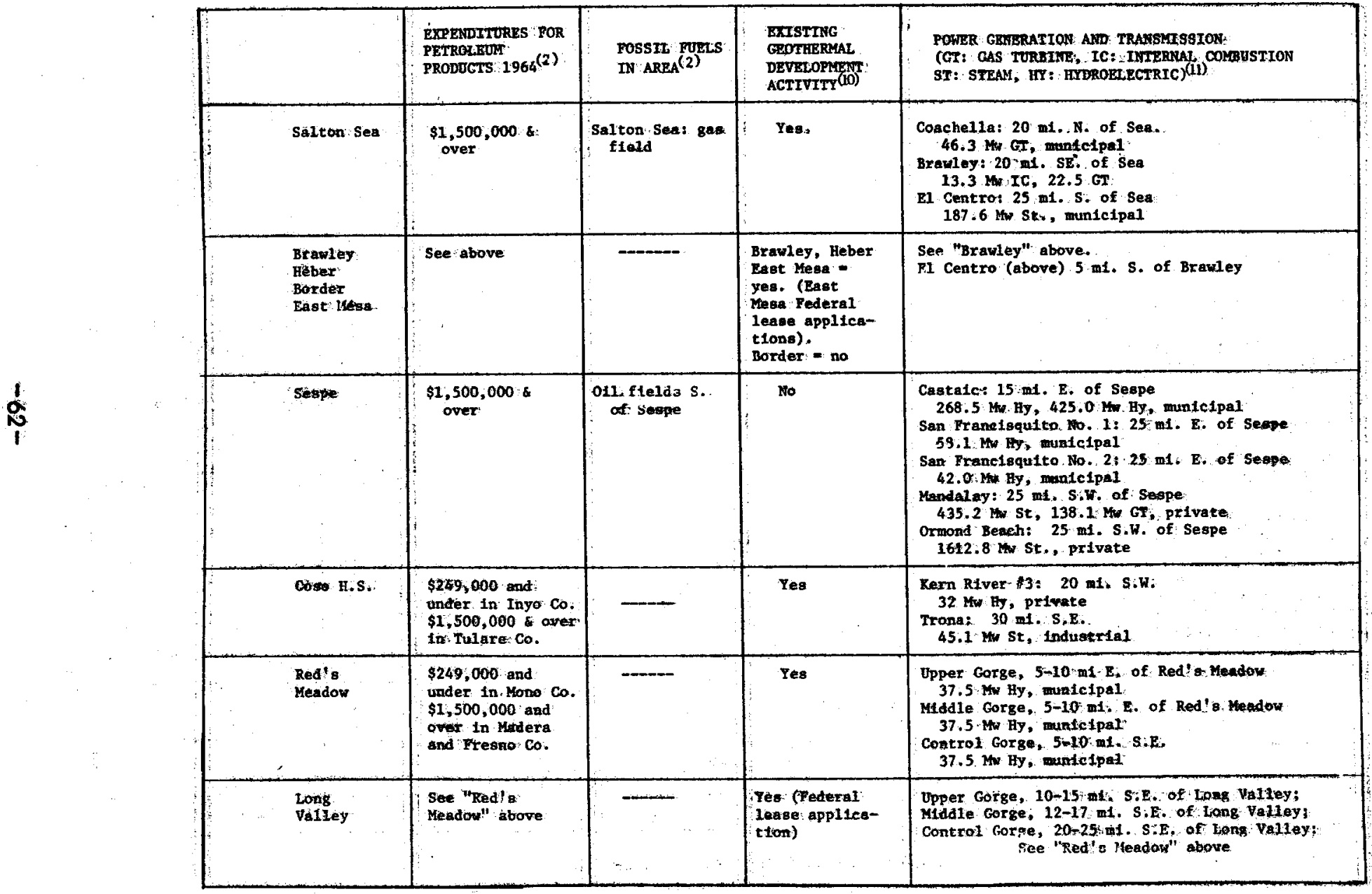


TABLE A-9

POPULATION AND DEGREE DAYS

\begin{tabular}{|c|c|c|c|c|}
\hline Site & $\begin{array}{c}\text { Population } \\
\text { Centers } \\
\text { (within } 30 \\
\text { mi. of site) }\end{array}$ & Population (5) & $\begin{array}{l}\text { Heating } \\
\text { Degree } \\
\text { Days }(4) \\
\end{array}$ & $\begin{array}{l}\text { Cooling } \\
\text { Degreq } \\
\text { Days } 4) \\
\end{array}$ \\
\hline $\begin{array}{c}\text { Salton } \\
\text { Sea }\end{array}$ & $\begin{array}{l}\text { Niland } \\
\text { Calipatria } \\
\text { Westmoreland } \\
\text { Mecca } \\
\text { Thermal } \\
\text { Salton City } \\
\text { Brawley } \\
\text { Imperial }\end{array}$ & $\begin{array}{r}950 \\
1,824 \\
1,417 \\
400 \\
600 \\
900 \\
14,300 \\
3,202 \\
\end{array}$ & $1000-2000$ & $3000-4000$ \\
\hline & TOTAL & 23,593 & & \\
\hline Brawley & $\begin{array}{l}\text { Brawley } \\
\text { Westmorland } \\
\text { Imperial } \\
\text { Calipatria } \\
\text { El Centro } \\
\text { Holtvile } \\
\text { Seeley }\end{array}$ & $\begin{array}{r}14,300 \\
1,417 \\
3,202 \\
1,824 \\
21,100 \\
3,496 \\
950 \\
\end{array}$ & " & $"$ \\
\hline & TOTAL & 46,289 & & \\
\hline Heber & $\begin{array}{l}\text { Heber } \\
\text { El Centro } \\
\text { Seeley } \\
\text { Calexico } \\
\text { Holtville } \\
\text { Imperial }\end{array}$ & $\begin{array}{r}950 \\
21,100 \\
950 \\
13,000 \\
3,496 \\
3,202 \\
\end{array}$ & " & " \\
\hline & TOTAL & 42,698 & & \\
\hline Border & $\begin{array}{l}\text { Border } \\
\text { East Mesa }\end{array}$ & - & " & $"$ \\
\hline $\begin{array}{l}\text { East } \\
\text { Mesa }\end{array}$ & $\begin{array}{l}\text { East Mesa } \\
\text { Border } \\
\text { Holtville } \\
\text { Brawley } \\
\text { Calexico } \\
\text { E1 Centro }\end{array}$ & $\begin{array}{c}- \\
- \\
3,496 \\
14,300 \\
13,000 \\
21,100 \\
\end{array}$ & $"$ & $"$ \\
\hline & TOTAL & 51,896 & & \\
\hline
\end{tabular}


TABLE A-9 (Concluded)

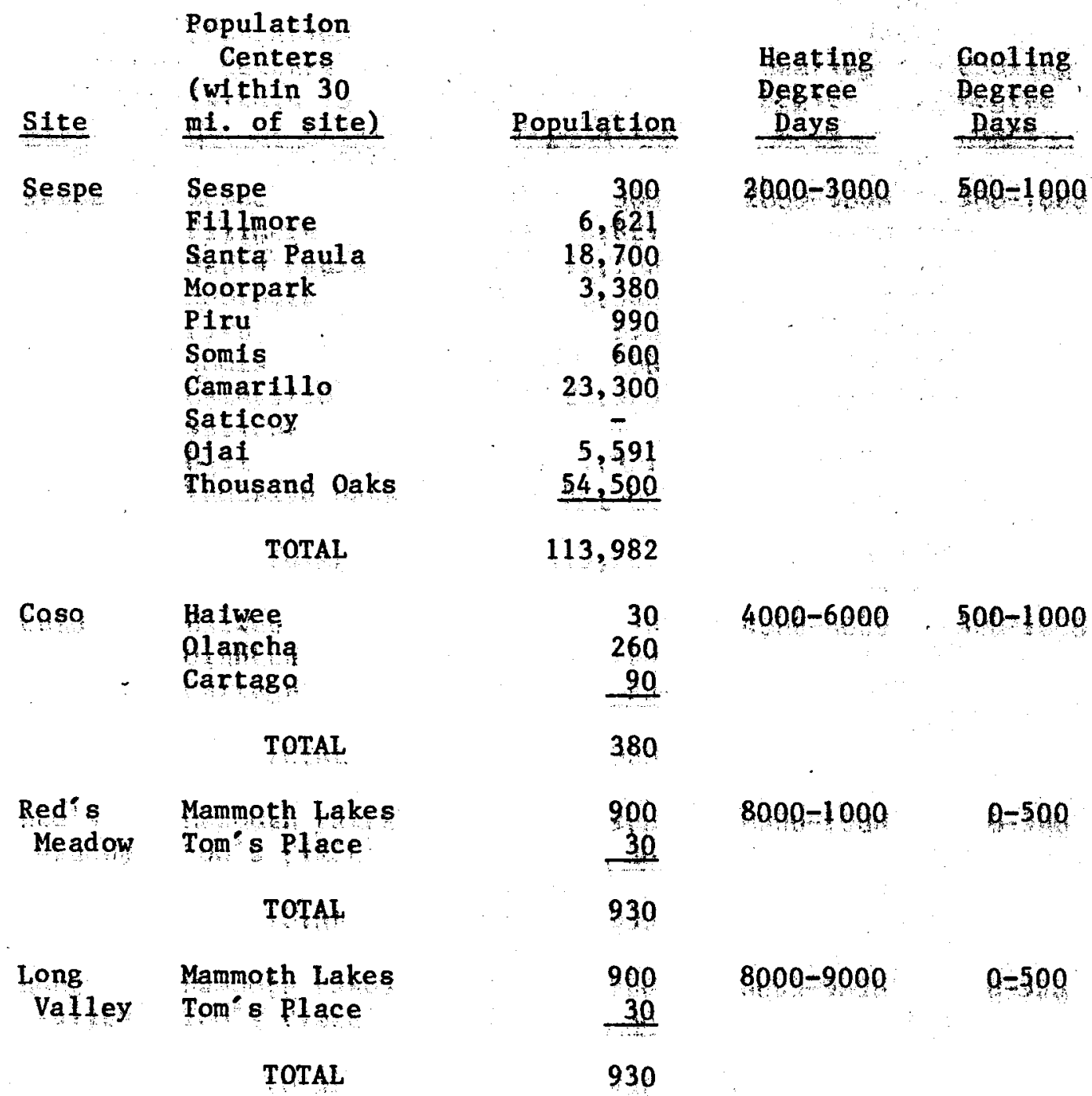


TABLE A-10

AIR AND WATER QUALITY

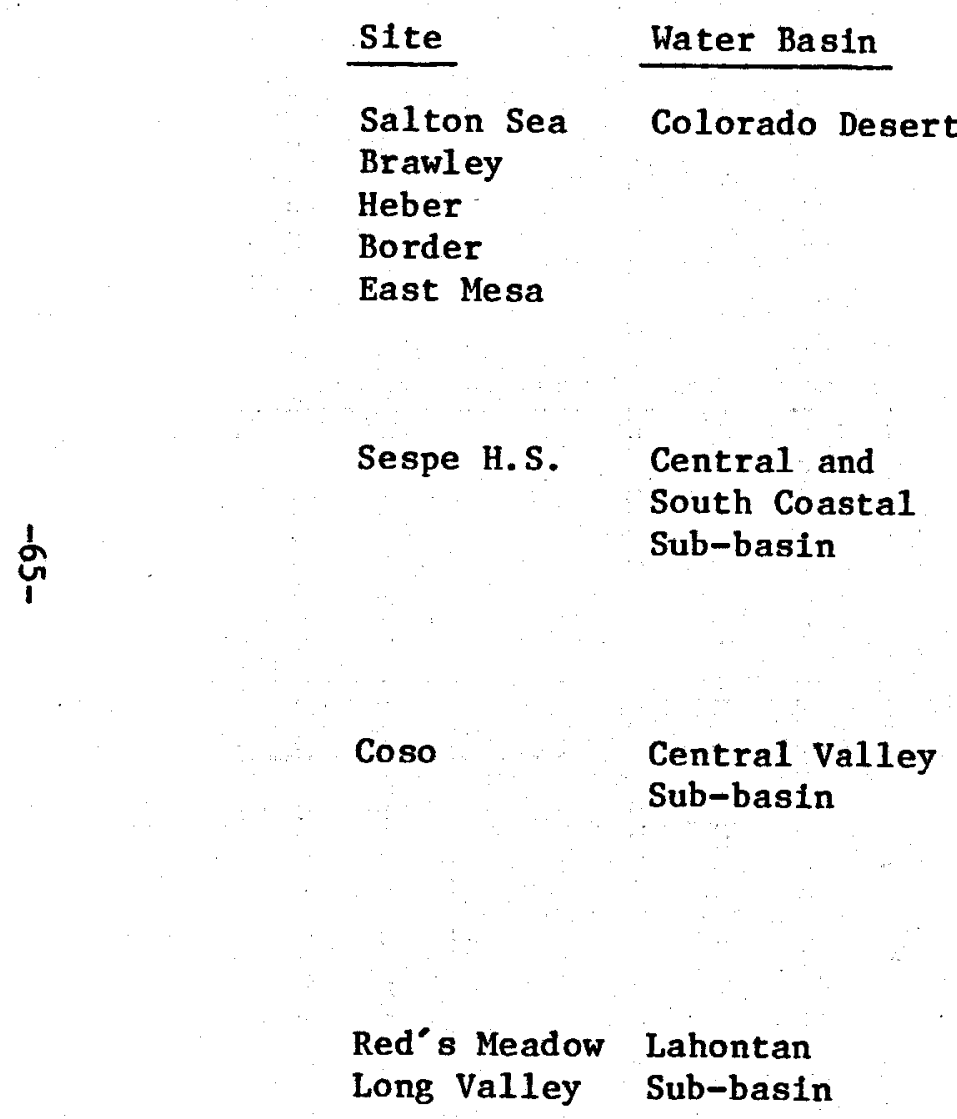

\begin{abstract}
Water Resources (12)
High salinity rate in water supply, water management problems of the Columbla River estuary and main-stem system. $(\geq 50 \%$ of stream miles polluted)
\end{abstract}

20-49.9\% of stream miles polluted (water atlas).

State vs. Federal water jurisdiction disputes. Deterioration of surface water quality. Some ground water overdraft, and land subsidence.
Air Pollution Days ${ }^{(4)}$

10-20 days of high air pollution potential forecasted.

20-30 days of high air pollution forecasted, high suspended particles and sulphur dioxide (from L.A. area).

30-40 days of high air pollution potential forecasted.

50-60 days of high air pollution potential forecasted. 
APPENDIX B

EVALUATTON AND SCORING

Once the site transformation table defined in section 3 is complied, the evaluation and scoring stage can ofegin: for this stane an evaluation table (Table B-1) hay be osed. A score 1 s oftren to each characteristic in the table. The score tepends on two factors:

(1) The suitability of the resource for development lndependent of the industry:

(2) The degree of matching of the speciflc source to the spectfic industry.

The scores presented in Table B-1 and explained in Tábie B-2 are preliminary: The data needed to confirm their validity are not presentiy available: It should be expected that this preiminary scoring procedure will be changed as data are collected and the procedure is refined by use.

The sum of the scores in any one fow ts the total for the particular criterion associated with the fow. After a total seofe is obtained for each row; the scores afe welghted by a relative lapportance factor: These latter numbers; when summed; will give an overall score for the sitelindustry application. A sum of the scores for all the industries considered for a particular reservot wili give an index for that site.

Discussion of scóting

The factors considered in the getreration of the scores for each element in the evaluation matix ares in order of importance: 
(1) Impact of the substitution of geothermal energy on fuel imports and on fuel savings.

(2) The suitability of the geothermal brine, as is, without modifications, for a particular application.

(3) Local conditions, 1.e., the degree of industrialization, avaflability of labor and raw materials, capacity of the transportation system, and laws and regulations.

(4) Modifications of pollution patterns. It is assumed that all industries considered will meet local, state, and Federal standards; however, variations in the pollution patterns are permitted.

(5) The desirability of the region to attract people and labor.

Based on the above considerations, scores for each element of the evaluation matrix were arbitrarily generated. Table B-2 defines the elements of each of these criteria and explains the scoring system. A score of +100 points was considered highly desirable and -100 highly undesirable. The scoring was so designed that a particular site/industry combination may have scores that can range from very large negative numbers to very large positive numbers (1.e., there is no maximum or minimum score), and in a group of these, those with the highest numbers will be most desirable.

The Weighting Procedure

To determine a weight for each criterion, as described in Appendix $C$, an emphasis curve was generated by polling ten members of the MITRE Geothermal Group. Although this method works best when the criteria vary little in importance between them, it did allow the ranking of the criteria and the generation of preliminary weights 
(shown in Table B-1) for use in the early stages of the evaluation phase. Again those weights must be revised if found unsatisfactory. 


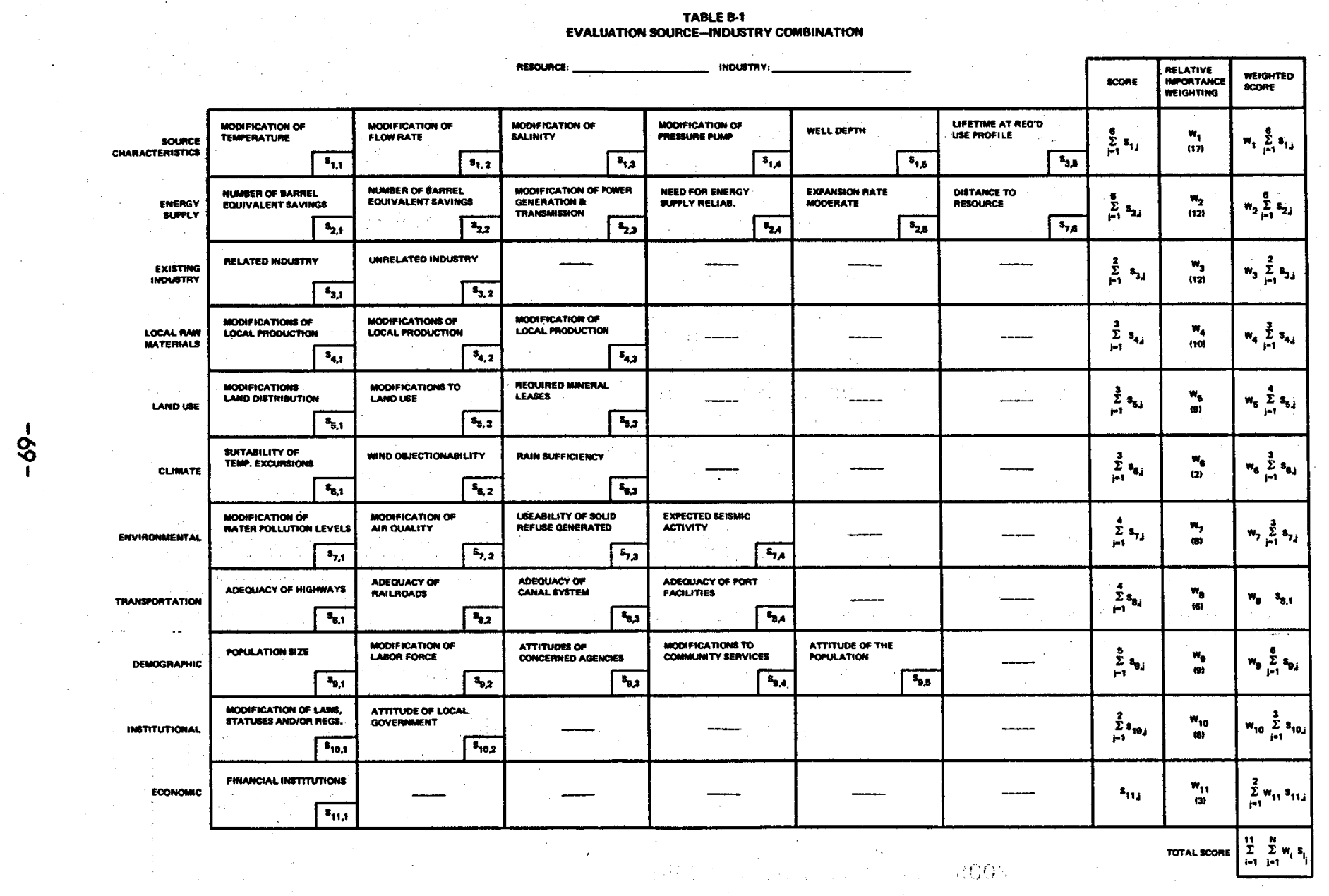




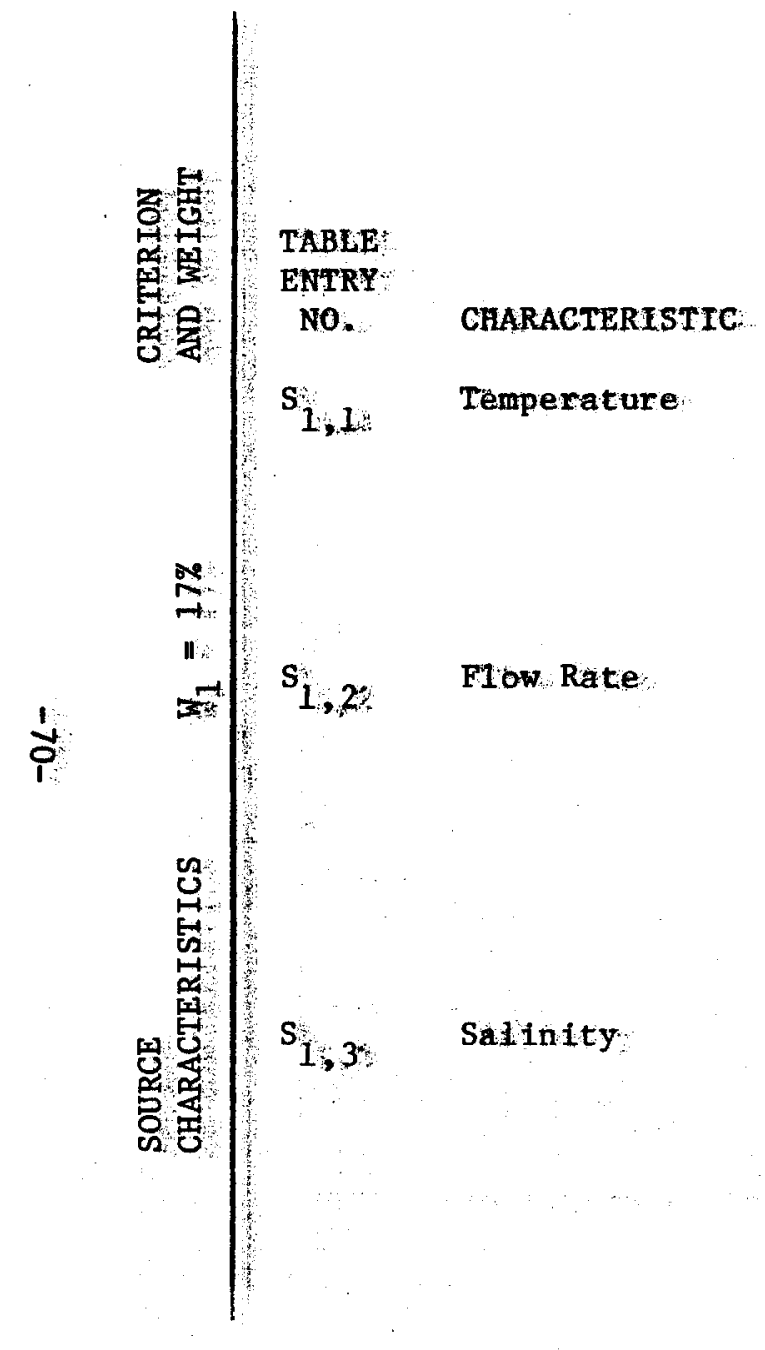

TABLE B-2

RESOURCE SITE/INDUSTRY SCORES

SCORE

REASEN

-50 for addtit lonal heating

-15 for cooling

+10 if within temperature

1imits

0 if at lowest tolerable

Iimits?

-50 for increase beyond: wel1 capactty.

-15 for motifications: withfin well capacity

+10 15 whth required

1 intits.

0 if close to lowest

tolerable: lifmit:

-100 if not tolerabile

-20 if secondan working

fluid required

+100 if pracess will tol-

erate high salinity

+10 if salinity within

toderane:

If a process requires modffication of the brine temperature, additional equipment (heat exchangers) mugt be installed

Modification of the flow rate whil also require finstallation of atat-m. tlonal equipment in this cases additional penalty points are glvet to increasing the filow rate beyond? the capactey of the wedr, requint the drflling of addte ond weils

$$
\text { -. }
$$

Installation of destintation equipment ig consudered highty: undesirable. A heat exchanger may. bee used to heat a secondary wikling fluid: A processolnsensitlue to salinity is conblatered hilghty destrable 


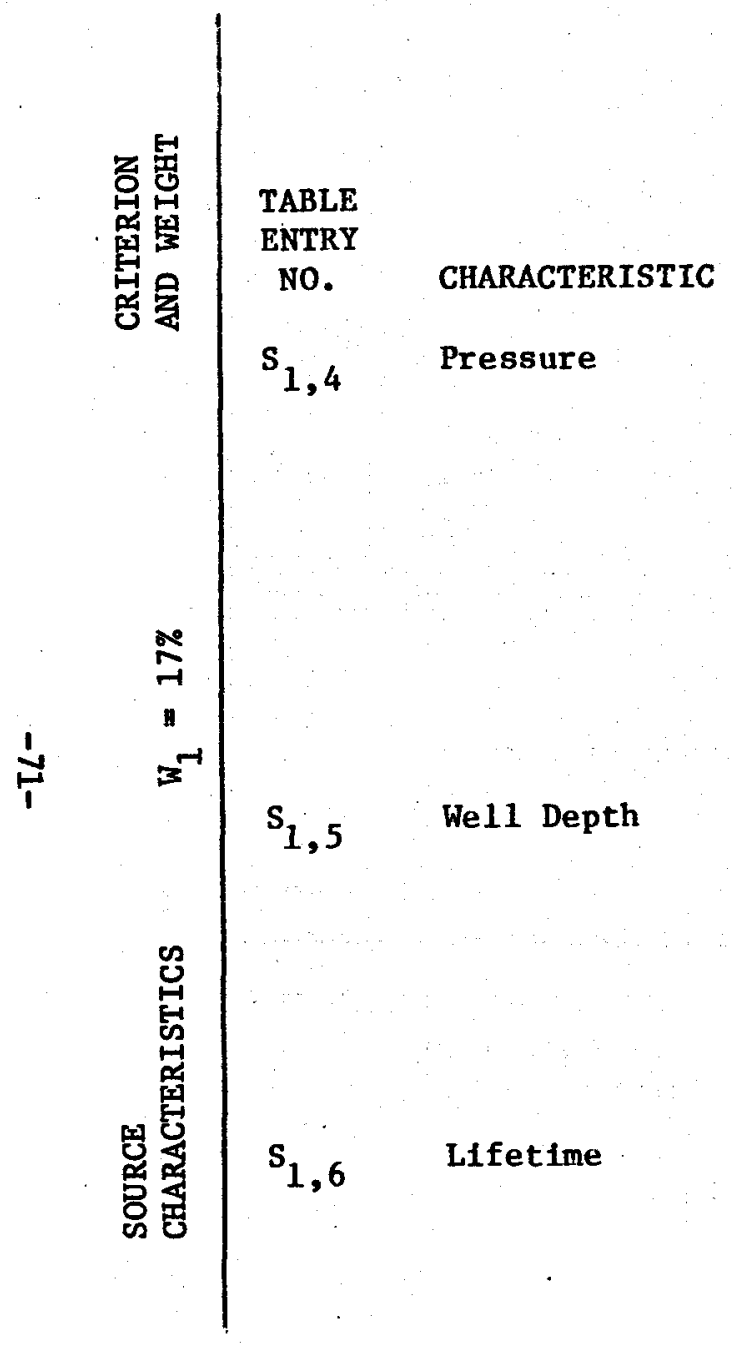

TABLE B-2 (Cont $t^{\circ}$ )

SCORE

-50 if downhole pump required

-25 if surface pump required

+20 if process will tolerate flash

+10 if pressure within ifmits

0 if pressure near allowable limits

$50(1-d / 3000)$ where $d$ is the well depth in feet

$50\left(1-\frac{100 Q R}{Q}\right)$ where $Q R$ is the yearly energy consumption of the industry. $Q$ is the estimated energy content of the reservoir

\section{REASON}

Due to the poor rellability of high temperature downhold pumps to date, they are considered less desirable than surface pumps. A process that will tolerate steam mixed with the brine is more desirable than one which can operate on fluids only

An average geothermal well is about $3,000 \mathrm{ft}$. deep. Hence a well shallower than $3,000 \mathrm{ft}$. is more desirable than one deeper. The 3,000 ft. cut-off should be modified for geopressured wells, where the average is around $12,000 \mathrm{ft}$.

In non-electric applications, it is possible to recover up to 25 percent of the heat content of the reservoir. The equation also reflects the fact that a reservoir must have sufficient energy to operate the Industry for at least 25 years 
TABLE B-2: (Cont'd)

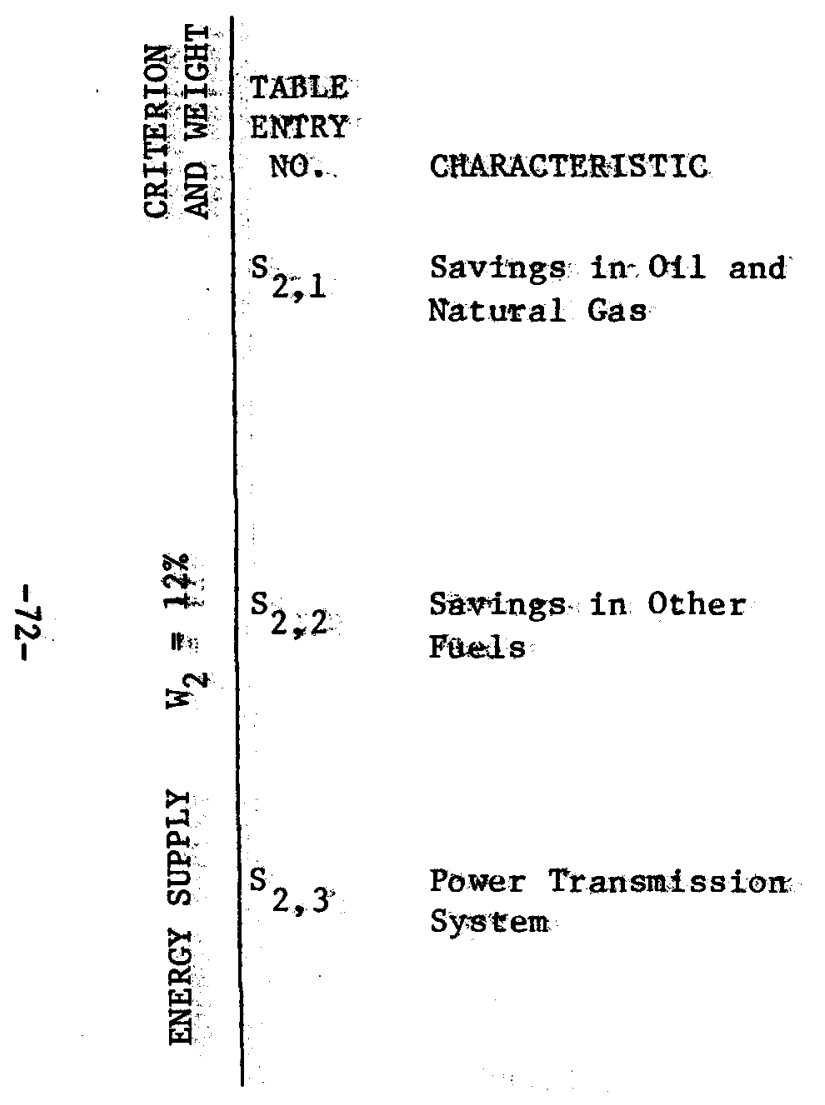

SCORE

$100\left(\frac{\mathrm{C}}{1000}\right)$ where $\mathrm{C}$ is the estimated oil and natural gas saved by use of geothermal energy in equivalent $\mathrm{BBL} / \mathrm{day}$

$25\left(\frac{C}{350}\right)$ where $C$ is the actual other fuels saved by use of geothermal energy:

-50 if major expansion is required

0 otherwise

+50 if transmisston system can handle power when generation is constidered
REASOW

The present ofl and natural gas consumption in the U.S. is around $30 \mathrm{milli}$ on equivalent BBL/day. In the equation, 100 points are given for each 1,000 equivalent BBL/day savings $(1 / 30,000$ of the dally consumption).

Present U. S. consumption of other fuels is around 10 million equivalent BBL/day. Since this supply is not in jeopardy, 25 points are given for a substitution of $1 / 30,000$ of the daily consumption

New industry may require major modifications to the electrical network. Sites in which modffications are not required are naturally more destraable. A site whose network can handle additional power generated geathermally is also moré deqtrable 
TABLE B-2 (Cont'd)

TABLE

ENTRY

No.

$\mathrm{S}_{2,4} \quad$ Supply Rellabllity

+20 if $100 \%$ is achieved by use of the geothermal source and $100 \%$ reliability is required by the process.

0 if $100 \%$ rellability not require.

-20 if rellability is decreased by use of geothermal energy.

$r\left(S_{2, \frac{1}{1}}+S_{2,2}+S_{2}\right)$
where is Ene fractional expansion rate of energy demand by the process

50. $\left(1-\frac{D}{20}\right)$ where $D$ is

distance to well in miles

Expansion Rate

Distance to Resource

\begin{abstract}
REASON
Some proceses require 24 hour operation and hence $100 \%$ rellability for the energy source. In that case, the geothermal source may provide the required rellability. On the other hand, it is possible that the use of geothermal brine may result in decrease of rellability because of corrosive effects of the brine.
\end{abstract}

If the source is not adfacent to the factory where the brine is to be used, the brine must be piped. This will result in a loss of energy as well as additional installation costs. 


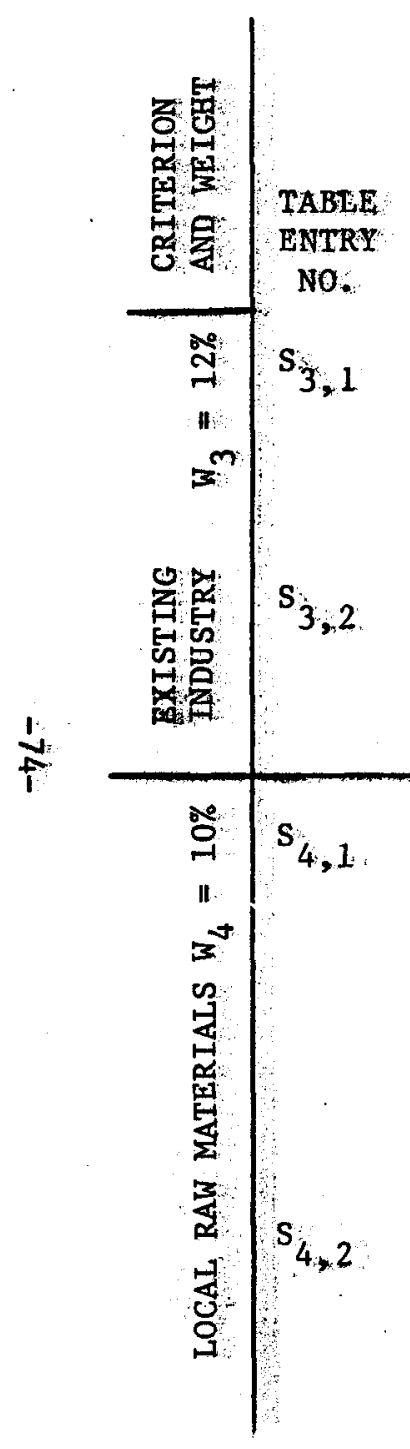

TABLE B-2 (Cont"d)

CHARACTERISTIC

SGORE

REASON

Related Industry.

+30 for each related indus- The avallabllity of related industry whether complementary try in the region has many advanor competitive tages including cost savings in transportation, labor availability, common imports, etc.

Unrelated Industry +5 for each unrelated industry.

The presence of unrelated industry in the region is a measure of the degree of commercialization of the region.

Existing Raw Mam terials for Related Industries:

+50 if modification in raw material production advantageous to region; -50 if not

0 if neither

Raw Materials for Unrelated Industry

Same as abore

A certafn process may require modfflcations in the raw material produetton of the region (eig., increase of beet production for a sugar factory). Such modification may improve the standard of living in the regtion, such as provide addltional fobs, make use of uncult tivated land, etc, or it may have the opposite ffect.

Same as above 


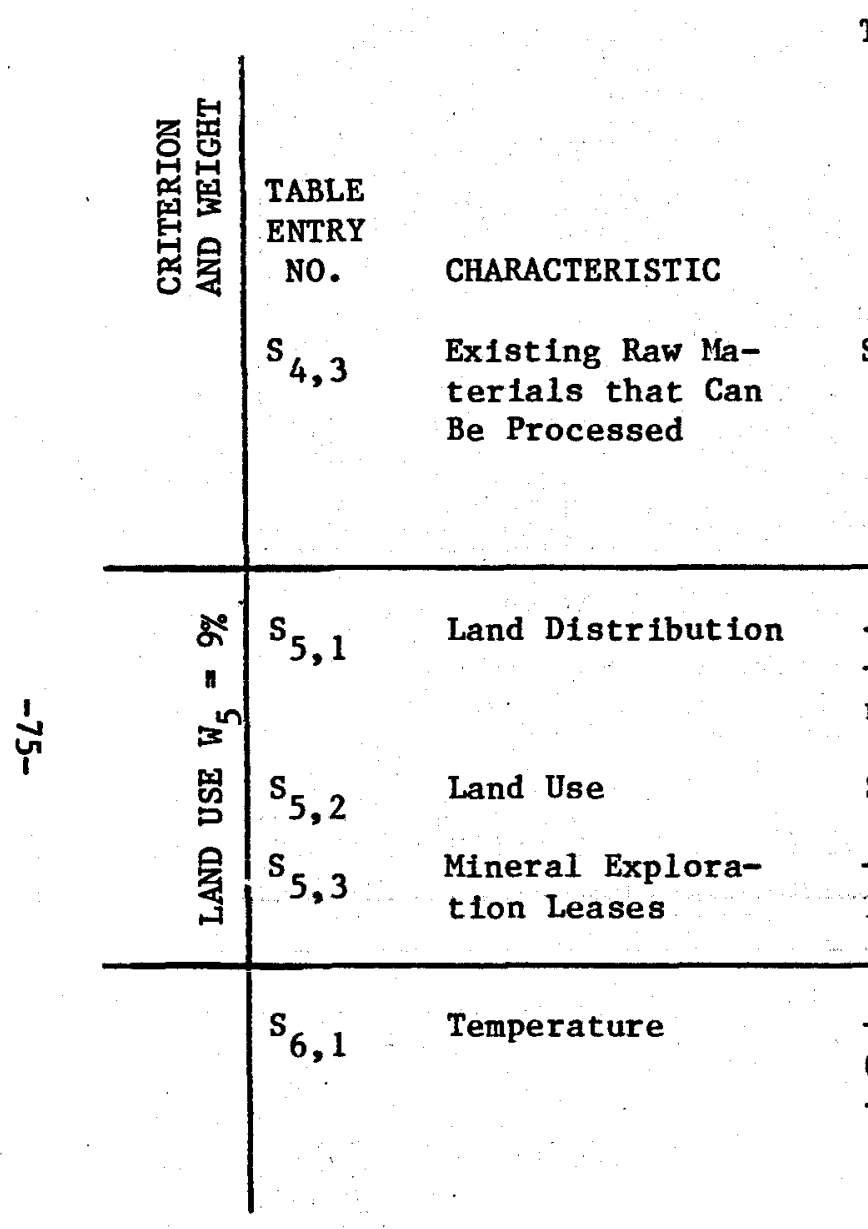

TABLE B-2 (Cont'd)

SCORE
Same as above $\begin{aligned} & \text { REASON } \\ & \text { A certain region may have the proper } \\ & \text { conditions to produce (or may be pro- } \\ & \text { ducing) a raw material that can be } \\ & \text { processed locally using geothermal } \\ & \text { energy. }\end{aligned}$

-50 for modifications +50 if no modifications required

Same as above

+25 for each mineral

lease

+50 if desirable

0 if average

-50 if undesirable
Any modifications in land distribution will require time and additional expenses thence delaying projects.

Same as above

Leases are indicative of possible future development of the region.
The dafly and yearly temperature excursions and climate in general will have some influence on the potential of a region to attract additional labor when necessary. 


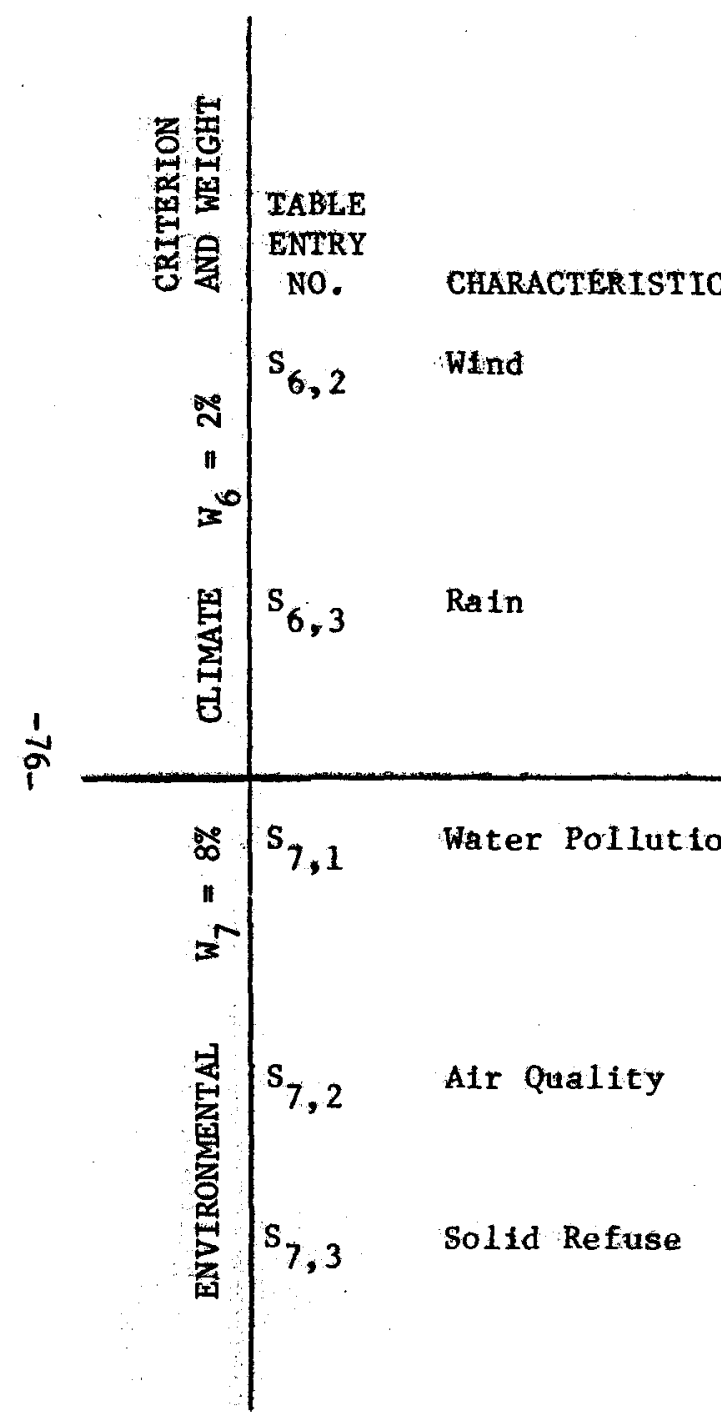

TABLE B-2 (Cont $\left.t^{\circ} \cdot d^{\prime}\right)$

SCORE REASON

0 if OK

-100 if intolerable

0 if $\mathrm{OK}$

-100 if intolerable
In most cases, the wind conditions should have very little effect on a process. In the case where it does and the wind is intolerable in the region a large penalty is assessed.

Lack of sufficient rain may require that some raw materials be imported from other areas insteat of being grown locally.

For consideration, the proces thist meet all pollution requirements. This characteristic is intended to score posstble varlations within the standards.

+100 if decreased $0-(-100)$ if increased

0 if no effect

+100 if usable

0 to -100 otherwise
Same as above

The process may generate solld refuse which thy be usable elisewhere or it thay have to be disposed of. 


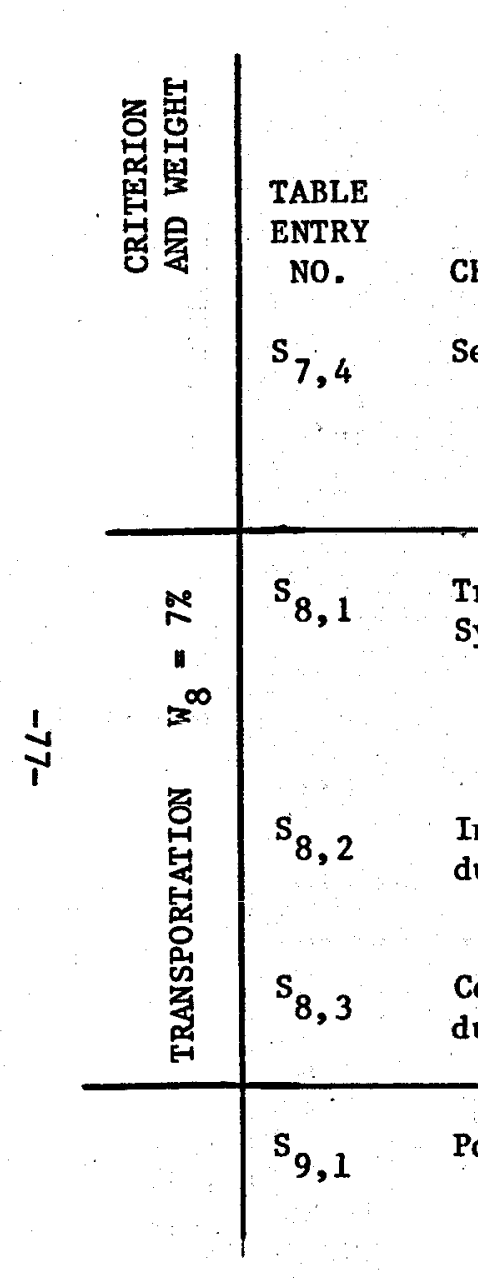

TABLE B-2 (Cont $t^{-}$)
CHARACTERISTIC
Seismic Activity

Transportation System

Industrial Products Center

Commercial Products Center
Population Size

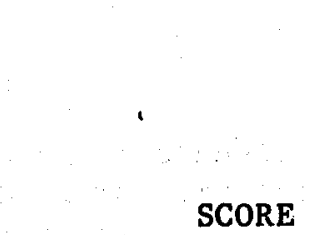

+100 if adequate (all modes)

0 to -100 if modifications required (any mode)

+100 if no restrictions -100 if restrictions require modifications

Same as above.

$$
\begin{aligned}
& 0-0-1,000 \\
& +10-1,000-2,500 \\
& +20-2,500-10,000 \\
& +30-10,000-50,000 \\
& +40-50,000 \text { and over }
\end{aligned}
$$

\section{REASON}

Reinjection will result in some selsmic activity. This must be thoroughly investigated before the go-ahead is given on a project.

Any new Industry will likely need to export its product and hence will require an adequate transportation system.

The proximity of the products center is of major importance for some industries

Same as above.

The larger the population of a region the larger is the likelihood of finding labor, of finding financing, of selling the product locally.. 


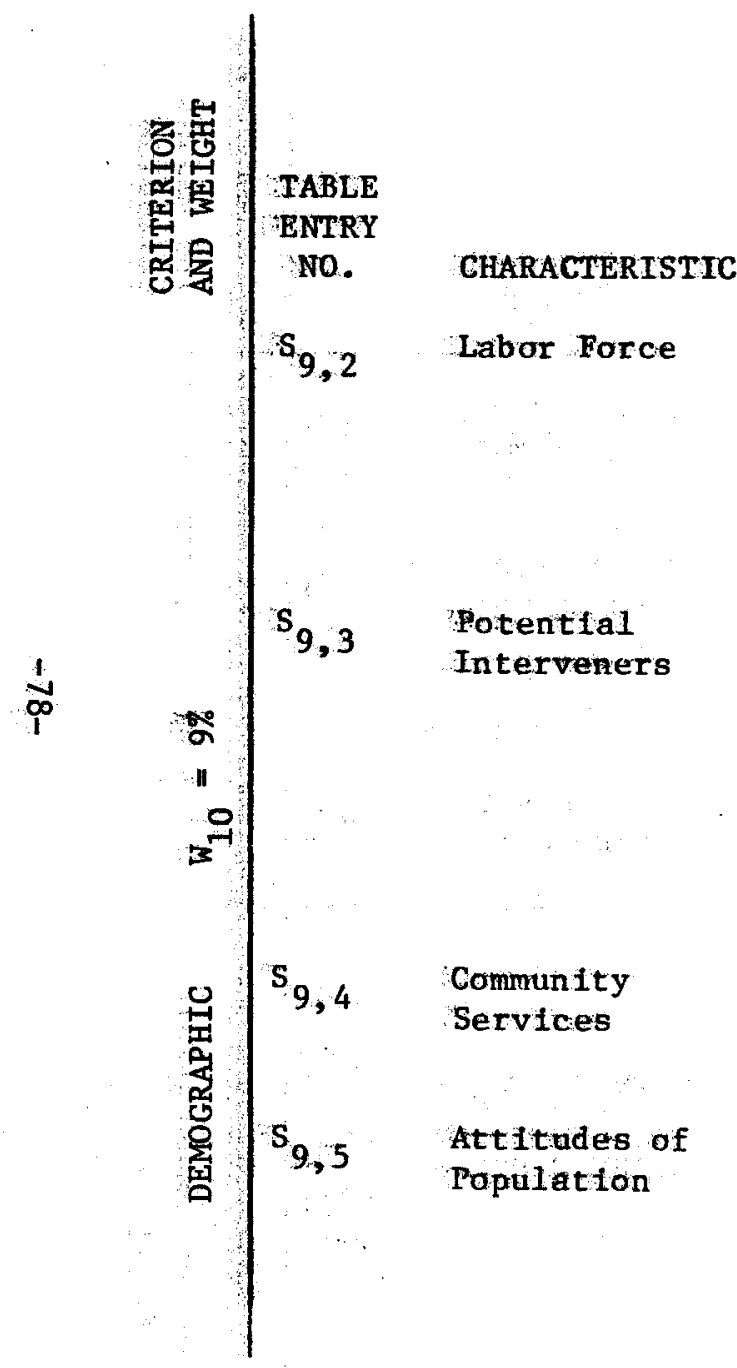

TABLE B-2 (Cont'd)

\section{SCORE}

-100 if labor force not available

+50 if OK

+100 if excess labor in

area will be used by new project.

-100 for each opposed agency

450 for each agency in favor

+50 if sufficient

0 to -100 for expansion

+100 if in favor

0 iff indifferent

-100 if opposed
REASON

A project is considered highly desirable if it results in the employment of excess labor in the region

As long as the public is uneducated in the area of geothermal energy, it can be easily nanipulated by agencles/groups pposed to geothermal development; hence a heavy penalty is assessed for each agency that fould oppose the development.

Community services such as schools, libraries, utilttles, etc, mist be adequate for a favorable score.

A population whtich seems in fravor of geothermal development is preferred to one opposed. 
TABLE B-2 (Cont $\left.{ }^{\circ} d\right)$

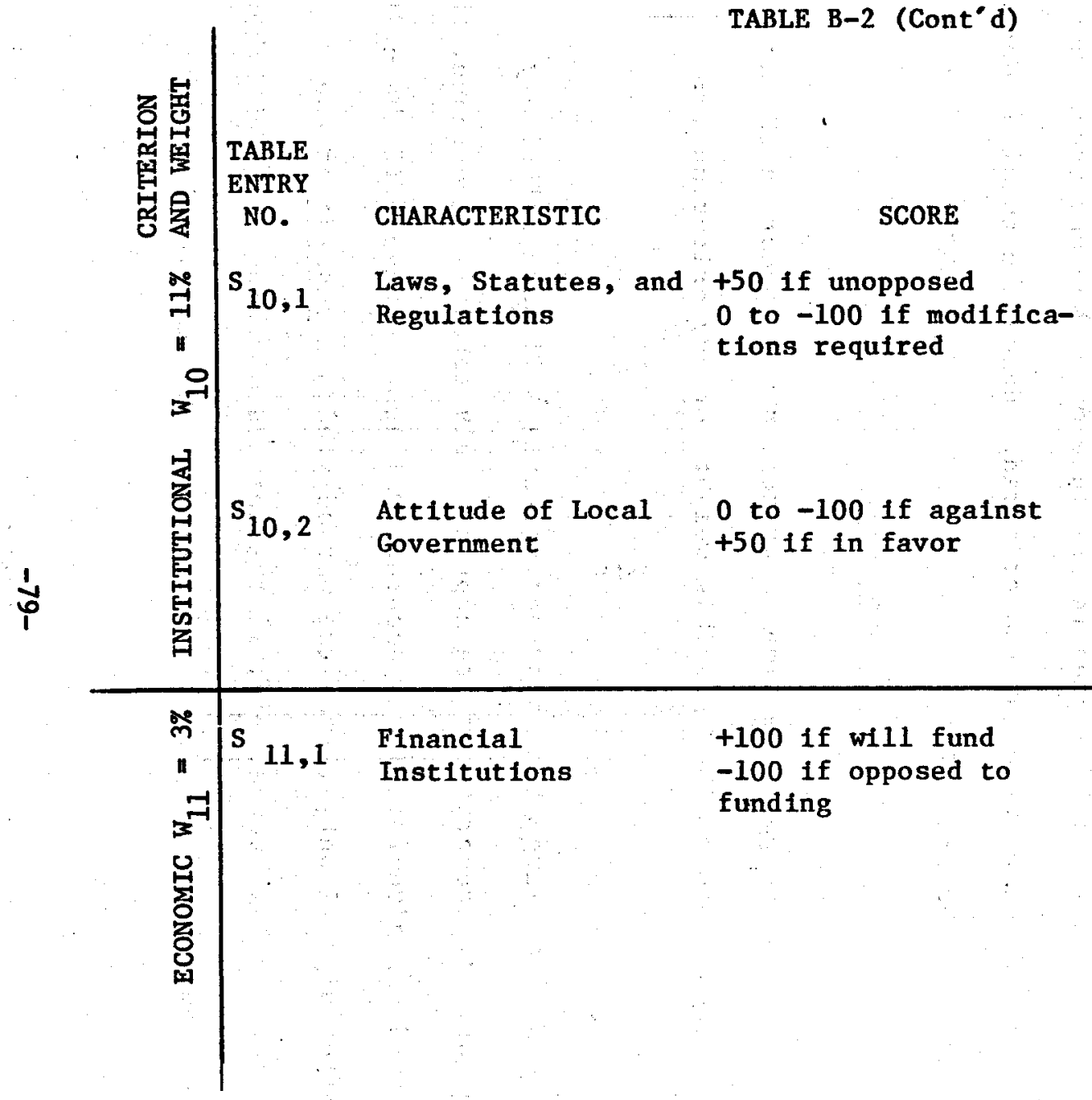

A negative grade ranging from 0 to -100 will be applied in cases where laws, statutes and/or regulations must be changed to accomodate geothermal development depending on the magnitude of the change.

The position of the officials opposed to geothermal development should be used to determine the negative score in cases where the local government is opposed to geothermal development

If the project is considered desirable and financial institutions will not fund $1 t$, $1 t$ will be the respons $1-$ bility of ERDA to provide funding. 


\section{APPENDIX C \\ WEIGHTING PROCEDURE BY USE OF \\ THE EMPHASIS CURVE}

To determine the relative weight of some of the critertat wed in this paper an emphasis curve technique was used: To fliffstrate the use of this method, assume that it is fiecessary to determitie the relative ithortance of $\mathrm{n}$ criteria, $\left(\mathrm{C}_{1}, \mathrm{C}_{2}, \ldots \mathrm{c}_{\mathrm{h}}\right)$. The wethod consists of displaying these criteria in th triangular artagy as shown in Figure C-1 (shown for ten criteria). The evaluators are then asked to write in each square which is the fintersection of $C_{i}$ with $C_{j}$ either $c_{i}$ or $c_{j}$, whichever they belleve is most ifiportant. The trlangular âriây is designed to preclude more than one occurrence of the comparison between any two criteria. Hence the total number of squares in the array is:

$$
\frac{n(n-1)}{2}
$$

and the 船ximum possible times a criterton may appear in the array is n-1: Hence the maximum posstble weight for any criterton ts:

$$
\frac{2}{n}
$$

As $n$ becoties large the important criteria will have relatevely tow wetght. If the critetia are apposimately equal in importance, the method can give relatively accurate weights. However, lif the criterfa differ slgnificantly, then the method yiejds a ranklng of the criterla only. Converselýg if the welgtits are close to each other then they should be a good indication of the relative importance of 
the criteria. However, if large differences occur, then the weights should only be used to indicate the relative ranking of the criteria examined. 


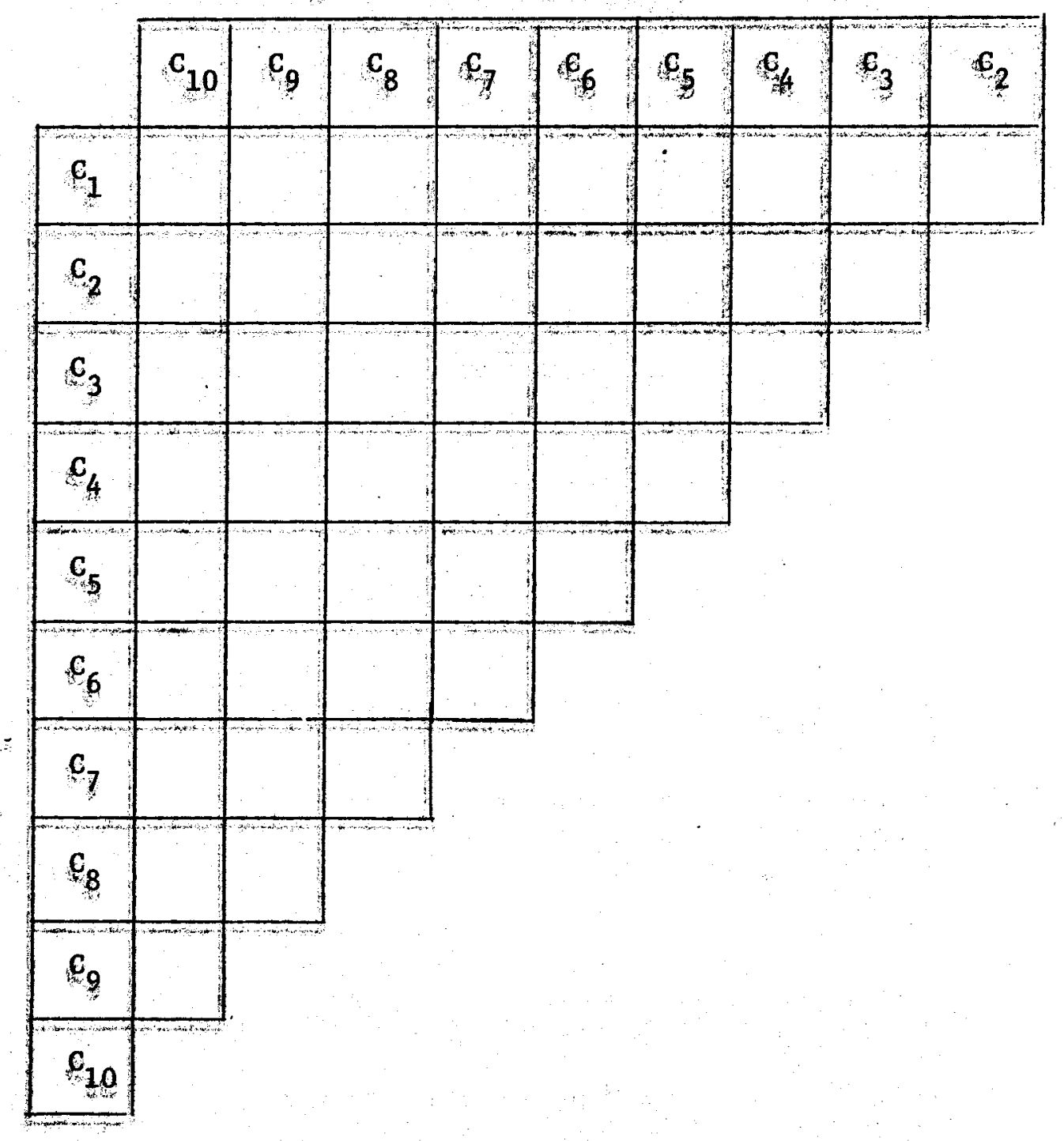

FIGURE 6-1

TRIANGULAR ARRAY FOR PAIR-WISE

COMPARISON OF TEN ERITERIA 
1. F.T. Grover, "Geothermal Energy Resource Utilization Program Planning," The MITRE Corporation, MTR-7137, McLean, Virginia, March 1976.

2. United States Geological Survey in cooperation with the Energy Research and Development Administration, Assessment of Geothermal Resources of the United States $-1975, D:$ F. White and D.L. Williams, eds., Circular 726, U.S. Geological Survey, Reston, Virginia, 1975.

3. United States Department of Commerce, Bureau of the Census, 1972 Census of Manufacturers, General Summary, MC72(1)-1, Washington, D.C., U.S. Government Printing Office, 1975.

4. United States Department of the Interior, Geological Survey, The National Atlas of the United States of America, Washington, D.C., 1970 .

5. Rand MoNally and Company, 1974 Commercial Atlas and Marketing Guide, 105th edition; Chicago, Illinois, 1974.

6. California Manufacturers Association, California Manufacturers Register, 1975, 28th ed., Sacramento, California, Times Mirror Press, 1975 .

7. United States Department of Commerce, Bureau of the Census, 1972 Census of Manufacturers, Fuels and Electric Energy Consumed, MC72(SR)-6, Washington, D.C., U.S. Government Printing Office, July 1973.

8. United States Department of Commerce, Soclal and Economic Statistics Administration, 1972 Census of Manufacturers, California, Area Serles MC72(3)-5, May 1975.

9. United States Department of the Interfor, "The Mineral Industry of California," Minerals Yearbook 1972, Vol. II, Area Reports: Domestic, Washington, D.C., United States Government Printing Office, 1974 .

10. Charles Frederickson, Jet Propulsion Laboratory, Personal Communication, Pasedena, California, March 11, 1976.

11. Federal Power Commission, Bureau of Pcwer, "Principal Electric Facilities," Southwestern Region, 1975.

12. United States Department of the Interior, Bureau of Reclamation, Executive Summary of Critical Water Problems Facing the Eleven Western States, Westwide Study, Washington, D.C., U.S. Government Printing Office, 1975. 